\title{
Record breaking achievements by spiders and the scientists who study them
}

\author{
Stefano Mammola ${ }^{\text {Corresp., }}{ }^{1,2}{ }^{2}$, Peter Michalik ${ }^{3}$, Eileen A Hebets ${ }^{4}$, Marco Isaia ${ }^{\text {Corresp. } 1,2}$ \\ 1 Department of Life Sciences and Systems Biology, University of Turin, Torino, Italy \\ 2 IUCN SSC Spider \& Scorpion Specialist Group, Torino, Italy \\ 3 Zoologisches Institut und Museum, Ernst-Moritz-Arndt Universität Greifswald, Greifswald, Germany \\ 4 School of Biological Sciences, University of Nebraska - Lincoln, Lincoln, United States of America \\ Corresponding Authors: Stefano Mammola, Marco Isaia \\ Email address: stefano.mammola@unito.it, marco.isaia@unito.it
}

Organismal biology has been steadily losing fashion in both formal education and scientific research. Simultaneous with this is an observable decrease in the connection between humans, their environment, and the organisms with which they share the planet. Nonetheless, we propose that organismal biology can facilitate scientific observation, discovery, research, and engagement, especially when the organisms of focus are ubiquitous and charismatic animals such as spiders. Despite being often feared, spiders are mysterious and intriguing, offering a useful foundation for the effective teaching and learning of scientific concepts and processes. In order to provide an entryway for teachers and students - as well as scientists themselves - into the biology of spiders, we compiled a list of 99 record breaking achievements by spiders (the "Spider World Records"). We chose a world-record style format, as this is known to be an effective way to intrigue readers of all ages. We highlighted, for example, the largest and smallest spiders, the largest prey eaten, the fastest runners, the highest fliers, the species with the longest sperm, the most venomous species, and many more. We hope that our compilation will inspire science educators to embrace the biology of spiders as a resource that engages students in science learning. By making these achievements accessible to nonarachnologists and arachnologists alike, we suggest that they could be used: (i) by educators to draw in students for science education, (ii) to highlight gaps in current organismal knowledge, and (iii) to suggest novel avenues for future research efforts. Our contribution is not meant to be comprehensive, but aims to raise public awareness on spiders, while also providing an initial database of their record breaking achievements. 
1 Record breaking achievements by spiders and the scientists who

2 study them

3

4

5

6 Stefano Mammola ${ }^{1,2,}$, Peter Michalik $^{3}$, Eileen Hebets ${ }^{4}$ \& Marco Isaia ${ }^{1,2,{ }^{* *}}$

7

8 1. Department of Life Sciences and Systems Biology, University of Torino, Torino, Italy

9 2. IUCN SSC Spider \& Scorpion Specialist Group, Torino, Italy

10 3. Zoologisches Institut und Museum, Ernst-Moritz-Arndt-Universität, Greifswald,

11 Germany

12 4. School of Biological Sciences, University of Nebraska-Lincoln, Lincoln, USA

13 * corresponding author: stefanomammola@gmail.com

$14^{* *}$ corresponding author: marco.isaia@unito.it

15

16

17 
18 Abstract

19 Organismal biology has been steadily losing fashion in both formal education and 20 scientific research. Simultaneous with this is an observable decrease in the connection 21 between humans, their environment, and the organisms with which they share the 22 planet. Nonetheless, we propose that organismal biology can facilitate scientific 23 observation, discovery, research, and engagement, especially when the organisms of 24 focus are ubiquitous and charismatic animals such as spiders. Despite being often 25 feared, spiders are mysterious and intriguing, offering a useful foundation for the 26 effective teaching and learning of scientific concepts and processes. In order to provide 27 an entryway for teachers and students - as well as scientists themselves - into the 28 biology of spiders, we compiled a list of 99 record breaking achievements by spiders 29 (the "Spider World Records"). We chose a world-record style format, as this is known to 30 be an effective way to intrigue readers of all ages. We highlighted, for example, the 31 largest and smallest spiders, the largest prey eaten, the fastest runners, the highest 32 fliers, the species with the longest sperm, the most venomous species, and many more. 33 We hope that our compilation will inspire science educators to embrace the biology of 34 spiders as a resource that engages students in science learning. By making these 35 achievements accessible to non-arachnologists and arachnologists alike, we suggest that they could be used: (i) by educators to draw in students for science education, (ii) to highlight gaps in current organismal knowledge, and (iii) to suggest novel avenues for future research efforts. Our contribution is not meant to be comprehensive, but aims to raise public awareness on spiders, while also providing an initial database of their record breaking achievements. 


\section{INTRODUCTION}

42 Organismal biology, or the study of the structure, function, ecology and evolution of 43 organisms, is critical for understanding the fundamental questions in ecology, 44 evolutionary biology, neurobiology, and more. In other words, organismal biology is 45 essential for science - for its practice, its teaching, and its learning (Schwenk et al., 2009). The intensive study and detailed understanding of specific organisms enables research programs that can address important and timely questions and topics, such as climate change, disease transmission, pest management, and biomaterial engineering (Maher, 2009; Alfred \& Baldwin, 2015). The natural world around us harbours surprises that even the most educated and creative minds could not fashion de novo (e.g., Bonabeau, Dorigo \& Theraulaz, 2000; Sarkar, Phaneendra \& Chakrabarti, 2008; Place, Evans \& Stevens, 2009; Grzybowski \& Huck, 2016). Thus, the study of organisms allows scientists and non-scientists alike to travel outside the limits of their own imagination.

Unfortunately, as a species, Homo sapiens is losing its collective knowledge, understanding, and appreciation of the organisms with which it shares the planet. There exists a growing trend for youth and adults alike to be increasingly physically inactive and, associated with this, to spend less and less time outdoors (Guthold et al., 2010; Hallal et al., 2012; Schaefer et al., 2014; Tremblay et al., 2014). Simultaneously, as science funding becomes harder and harder to acquire, basic natural history information and organism-based studies are more difficult to not only justify, but also to publish (Greene, 2005; Middendorf \& Pohlad, 2014; Tewksbury et al., 2014; Lo Presti et al., 2016). Additionally, in higher education there has been an increasing emphasis on pedagogical tools and practices that focuses on learning objectives, associated with broad concepts and critical thinking, with less focus on skills of observation and foundational facts associated with organismal biology (McLaughlin \& Metz, 2016; Fleischner et al., 2017). The result is that it is more and more difficult to expose teachers, learners of science, and scientists themselves to the incredible wealth of facts, wonders, and curiosities offered by organismal biology - see, e.g., the numerous examples in Carwardine (2008).

Despite the movement away from organismal biology among the general public, 
72 teachers and students of science, as well as among many scientists, human curiosity 73 and intrigue persists. This curiosity and intrigue is best demonstrated by the purity with 74 which it is observed in our youth. Some of the first words that children learn or noises 75 children make are animal-specific - e.g. the multiple "first words" books for babies and 76 toddlers (e.g., Priddy, 2004; Machell, 2005). Similarly, animal-related stories are common among early reading children's books, presumably because they can attract and retain a child's interest and attention. Even among adults, animals remain a useful tool for attracting attention and making connections among diverse societies, as evidenced by the numerous viral videos focused on cats, dogs, and other animals. Following from these observations of human interest in animals, we contend that organismal biology, especially the biology of particularly charismatic organisms, can still be an extraordinarily useful tool for engaging people of all ages in science-related teaching and learning and importantly can remain a source of inspiration for innovate, ground-breaking scientific studies.

Spiders and arachnids in general, are animals that can simultaneously instill both terror and intrigue. Their charismatic nature makes it extraordinarily easy to attract even the most bio-phobic individual into arachnid-based discussions and activities. Arachnids tend to be either loved or feared (and "hated"), with few people feeling ambivalence towards them (Hillyard, 1994; Mulkens, de Jong \& Merckelbach, 1996; Woody, McLean \& Klassen, 2005; Rinck \& Becker, 2007; Knight, 2008). Even a fear of spiders, however, can be harnessed towards the goal of enhancing science teaching and learning, because they are able to evoke such strong reactions. For example, arachnophobic individuals in particular demonstrate enhanced recall to spider-relevant information (Smith-Janik \& Teachman, 2008).

In addition to their charismatic nature, spiders are widespread and abundant, making them familiar and readily accessible to people everywhere. Compared to most organisms, they are understudied, thus providing opportunities for scientific discovery that could empower scientists and non-scientists alike with prospects of personal scientific contributions. They are also suitable model organisms for laboratory and field

101 experimentation, making it easy to facilitate hands-on science. Perhaps most importantly, however, is the fact that spider ecology and evolution is fertile ground for 
103 teaching a breadth of Science, Technology, Engineering, and Mathematic (STEM) 104 concepts.

105 For example, spider silk can be used to explore topics ranging from evolution of

106 form and function, to biomaterial engineering, to the physical properties of protein fibers

107 (e.g., Hinman, Jones \& Lewis, 2000; Heim, Keerl \& Scheibel, 2009). Knowledge of 108 spider natural history and habitat use can inform pest management practices (Nyffeler \& 109 Benz, 1987; Marc \& Canard, 1997), and biodiversity conservation efforts (Cardoso et 110 al., 2004). Spider sensory and locomotory systems can inspire technological innovation 111 (King, 2013; Kang et al., 2014) and spider venom can inspire medical and 112 pharmaceutical innovations (Bode, Sachs \& Franz, 2001; Saez et al., 2010; King \& 113 Hardy, 2013). In essence, we contend that spider biology can be used as a foundation

114 for teaching a range of topics and subjects at any level of education (K-12 or higher 115 education). However, to facilitate the implementation of spider biology as a resource for 116 teaching, learning, and research inspiration, the scientific background information needs

117 to be accurate and accessible - and preferably published in a clear and enjoyable way 118 (e.g., Sand-Jensen, 2007; Heard, 2014).

119 Towards our goal, we compiled a database of record breaking spider 120 achievements. In presenting our database, we take advantage of the reality that 121 humans often tend to think in extremes. Indeed, for people of all ages, the entire range 122 of superlatives exerts a powerful spell on human curiosity. Scientists are no exception, 123 as they are similarly attracted by formidable species and record breaking biological 124 discoveries (e.g., Watson \& Walker, 2004; Edwards et al., 2005; Glaw et al., 2012; 125 Sendra \& Reboleira, 2012; Wilson et al., 2012; Andersen et al., 2015; Klug et al., 2015; 126 McClain et al., 2015). Thus, we present our findings in a world-record style format, as 127 this is known to be an effective way to engaging youth and adults alike.

128 Numerous spider-related world records have already been claimed in peer129 review scientific papers (e.g., Jäger, 2001; Kuntner \& Coddington, 2009; Agnarsson, 130 Kuntner \& Blackledge, 2010; Lepore et al., 2012; Smithers \& Whitehouse, 2016).

131 Officially, spiders hold 44 Guinness World Records related to their biology (see 132 Guinness World Records - GWR, 2017; full list in Supplementary materials 1). Here, 133 we explore the scientific literature to provide a broader overview of record breaking 
134 achievements by spiders. We in no way intend this to be an exhaustive list, but more of 135 a "highlight" that can provide an entryway into the biology of spiders. Our goal is to 136 make these achievements accessible to both non-arachnologists and arachnologists.

137 We suggest that such a database can: (i) be used by educators to draw in students for 138 science education, (ii) highlight gaps in current organismal knowledge, and (iii) suggest 139 novel avenues for future research efforts.

140 We begin our synthesis of record breaking achievements with a brief introduction 141 to spiders followed by a presentation of record breaking achievements organized into 142 eight distinct categories (Table 1). 


\section{A BRIEF INTRODUCTION TO SPIDERS}

145 Spiders (Araneae) belong to the class Arachnida together with ten other orders: 146 scorpions (Scorpiones), harvestmen (Opiliones), pseudoscorpions (Pseudoscorpiones), 147 windscorpions (Solifugae), mites and ticks ("Acari"), micro-whip scorpions (Palpigradi), 148 hooded tickspiders (Ricinulei), tailless whipscorpions (Amblypygi), and shorttailed 149 whipscorpions (Schizomida) and whipscorpions (Uropygi) - common names based on 150 Breene et al. (2003). All spiders are hypothesized to have descended from a common 151 ancestor (i.e. they represent a monophyletic group; Garrison et al., 2016; Wheeler et al., 152 2016) and the group encompasses nearly 47,000 extant species, distributed among 153 4,072 genera and 112 families (World Spider Catalog - WSC, 2017). They are 154 considered to be one of the most successful groups of organism in terms of their long evolutionary history and diverse ecological impacts - they are distributed in virtually all

156 terrestrial ecosystems and play a key role as generalist carnivorous predators (Turnbull, 157 1973; Foelix, 2011). Indeed, a recent study by Nyffeler \& Birkhofer (2017) estimated 158 that the global spider community consumes between 400 and 800 million tons of prey 159 annually.

160 The body of a spider is divided in two parts: (i) the prosoma (or cephalothorax) 161 and (ii) the opisthosoma (or abdomen). These two body parts are joined by a narrow 162 stalk called pedicel (Figure 1). The prosoma is relatively hard and carries six pair of 163 appendages: the chelicerae, the pedipalps, and four pair of walking legs. The chelicerae 164 function in spider feeding and venom injection takes place through their fangs. Posterior 165 to the chelicerae are the pedipalps - the first pair of appendages behind the mouth. 166 The pedipalps of adult males are modified into copulatory organs and facilitate the 167 transfer of sperm to mature females. The four pair of walking legs are posterior to the 168 pedipalps. All walking legs originate from the prosoma, unlike the way they are 169 sometimes portrayed in spider merchandise - e.g. attached to a single body part or 170 inaccurately originating from the opisthosoma. In addition to the six pair of appendages, 171 the eyes are also located on the prosoma. Most spiders possess eight eyes, but in 172 some species this number may be reduced or eyes may be entirely lacking. Though 173 they do not have traditional ears, spiders can detect vibrations with slits in their cuticle 
174 (slit sensilla and lyriform organs) located on their walking legs. They can also detect

175 airborne particle movement with long thin hairs located across their body.

176 The second body part — the opisthosoma - is soft, expandable, and shows high

177 variation in shape and pattern among species (Figure 1). The abdomen of spiders

178 houses the respiratory system, the heart and most of the circulatory system, most of the

179 digestive system, the excretory system, the silk producing system, and the reproductive

180 system. In addition to these internal systems, the genital openings are located on the 181 underside (i.e. ventral surface) and are barely visible in mature males and immatures. In

182 females of most spiders, the genital opening can be covered by a hardened (i.e.

183 sclerotized) structure, the epigyne. At the back end of the opisthosoma most spiders

184 have their spinnerets, which are used for producing silk. Depending upon the species, a 185 single spider can possess up to eight types of silk glands, each extruding a distinct type

186 of silk. Silk is deployed in almost every aspect of a spider's life, from web construction to 187 egg protection (Foelix, 2011). 


\section{METHODS}

190 We began the compilation of the Spider World Records by verifying all available

191 biological records on spiders reported in the Guinness World Records (GWR) official

192 database (see Supplementary materials 1). Wherever we observed discrepancies

193 between the information found in the official GWR and that found in the scientific

194 literature, we provide details in the relative record sections. A thorough search of the

195 available literature was then conducted to track further documentations of extremes in

196 spider biology. This included finding peer-reviewed articles by means of literature

197 searches engines (Google Scholar, Scopus, Web of Sciences) but also personal

198 communications with arachnologists and other scientists conducting research on the

199 topics under evaluation (i.e., expert-based opinion). Most records related to taxonomy 200 were compiled exploring the online catalog of spiders (WSC, 2017), including updated 201 species counts and all literature on spider taxonomy from 1757 to date. 


\section{SPIDER WORLD RECORDS}

205 I. Arachnology and Arachnologists

206

207

208

209

210

211

212

213

214

215

216

217

218

219

220

221

222

223

224

225

226

227

228

229

230

231

232

(a) First arachnologist in history - Carl Alexander Clerck (1709-1865). Although reports about spiders can be found in very old writings such as those of Aristotle and Pliny, according to Bonnet (1955) the father of the modern arachnology was Carl Alexander Clerck, author of the first book on spiders using the binomial system of nomenclature, Svenska Spindlar (Clerck, 1757). His book was published only one year before the seminal "Systema Naturae" of Carl von Linné (Linneaus, 1758), which marks the beginning of the binomial system of nomenclature. In order to consider Clerck's spider descriptions valid under the system of zoological nomenclature, his work is deemed to be published on 1 January 1758 , which is regulated in the International Code of Zoological Nomenclature (Article 3.1; ICZN 1999).

(b) Most prolific arachnologist - Eugène Simon (1848-1924). In terms of publications, the most prolific arachnologist was the French naturalist Eugène Louis Simon. Over his life, he authored more than 270 spider-related scientific works, and he described (or revised the status) of 5,633 species - although some of them were later synonymized or considered nomen dubia (WSC, 2017). (Figure 2b)

(c) First catalogue of spiders - 1942. Carl Friedrich Roewer (1881-1963) own the record for publishing the first catalogue of spiders, i.e. the first volume of "Katalog der Araneae von 1758 bis 1940", published in 1942 (Roewer, 1942; see also Roewer, 1955). It included the list of spider species, synonyms and references published from 1758 to 1940 . This remarkable publication provided the baseline, together with the competing catalog of Bonnet $(1955,1956,1957,1958,1959)$ for further implementations (e.g., Brignoli, 1983; Platnick, 1989; 1993; 1998), up to the complete online taxonomic catalogues of spiders developed in the last decades (Platnick, 2000-2014; WSC, 2017; see also World Spider Catalog Archive, 2014-2017). 
233

234

235

236

237

238

239

(d) Longest publication on spiders - Bibliographia Araneorum. With 6,481 pages, the longest publication on spiders is the Bibliographia Araneorum (Bonnet, 1955, $1956,1957,1958,1959)$, representing the culmination of 40 years of work of the French arachnologist Pierre Bonnet (1897-1990).

(e) First congress of Arachnology - Germany, 1960. The first scientific arachnological meeting was held at the University of Bonn (Germany) in 1960. It was organized by Ernst Kullmann (1931-1996). According to the congress photo, at least 18 arachnologists attended this meeting (Kraus, 1999). (Figure 2c)

(f) Most attendees at a congress of arachnology - 365. With 365 participants, the $20^{\text {th }}$ International Congress of Arachnology (2-9 July 2016, Golden, Colorado, USA) was the largest arachnological congress ever held. It was organized by Paula Cushing (Denver, USA). (Figure 2d)

\section{Paleontology}

(a) First described fossil - An amber spider. According to Selden \& Penney (2010), the earliest illustration of a fossil spider (an unidentified amber spider) can be found in Kundmann (1737: plate XII, Fig. 13).

(b) Oldest fossil spider - 300 Myr ago. The oldest known true spiders date back to the Carboniferous age, around $300 \mathrm{Myr}$ ago. Most likely, specimens of Palaeothele montceauensis (Selden) (Mesothelae) are the earliest described fossil species, from the Upper Carboniferous (Stephanian) of Montceau-lesMines, France (Selden, 1996; GWR, 2017).

(c) Oldest fossil spider in amber - 125-135 Myr ago. The oldest described amber spider (125-135 Myr ago) is an undetermined Linyphiinae, preserved in a small piece of Lebanese amber (Penney \& Selden, 2002; GWR, 2017). This fossil specimen is also the oldest linyphiid spider known to date.

(d) Oldest recorded spider silk - 140 Myr ago. Although spiders are known to produce silk since the Mid-Devonian (410 Myr ago), the oldest spider silk record dates back to the Earliest Cretaceous ( 140 Myr ago). The silk is preserved in a 
piece of amber, which was found within alluvial soils of the Ashdown Formation, Hastings (Brasier, Cotton \& Yenney, 2009; GWR, 2017).

(e) Oldest web with entrapped prey - 110 Myr ago. The oldest web with entrapped 
(a) First spider(s) ever described in binomial nomenclature - Shared by 68 species. The record for the first spider ever described in binomial nomenclature is shared by 68 species described by Carl Alexander Clerck in 1757. Actually, some of them are nowadays considered doubtful species, leaving the total to 53 currently valid species (WSC, 2017). These species own a second record, being among the first animals ever described using the binomial system of nomenclature (see also "First arachnologist in history"). (Figure 2a)

(b) First listed spider alphabetically - Abacoproeces molestus Thaler (Linyphiidae). Abacoproeces molestus is the first valid spider species listed alphabetically in the World Spider Catalog. It is worth mentioning that Abacoproeces brunneipes (Dahl) would be the first spider name listed alphabetically, but this species is currently considered a junior synonym of $A$. saltuum (L. Koch) (WSC, 2017).

(c) Last listed spider alphabetically - Zyuzicosa zeravshanica Logunov (Lycosidae). Zyuzicosa zeravshanica is the last spider species listed alphabetically in the World Spider Catalog (WSC, 2017).

(d) Longest scientific name - Acanthoscurria hirsutissimasterni Schmidt (Theraphosidae). This spider's name has thirty-three characters. Names with thirty-two characters are more common, such as Alloclubionoides wolchulsanensis (Linyphiidae), Anophthalmoonops thoracotermitis (Oonopidae), Mecysmauchenioides nordenskjoldi (Mecysmaucheniidae), Megalepthyphantes pseudocollinus (Linyphiidae), and Troglohyphantes typhlonetiformis (Linyphiidae).

(e) Shortest scientific name - Gea eff Levi (Araneidae). This spider has only six characters in its name. Names with seven characters are found in the genus Ero (Mimetidae) and Copa (Corinnidae).

(f) Largest spider family - Jumping spiders, family Saltidicae. The largest spider family is Salticidae with more than 6,000 species currently described, distributed in 634 genera (WSC, 2017; see also GWR, 2017).

(g) Smallest spider family - Huttoniidae and Trogloraptoridae. The smallest families of spiders are Huttoniidae and Trogloraptoridae, both of which include one single 
species - Huttonia palpimanoides O. Pickard-Cambridge and Trogloraptor marchingtoni Griswold, Audisio \& Ledford, respectively. H. palpimanoides is endemic to New Zealand (Paquin, Vink \& Dupérré, 2010) while T. marchingtoni was discovered in few caves in southwestern Oregon, USA (Griswold, Audisio \& Ledford, 2012).

(h) First entire genome sequenced - Stegodyphus mimosarum Pavesi (Eresidae). In

(i) Most species named after celebrities within one genus - Caribbean Spintharus species. The International Code of Zoological Nomenclature (ICZN, 1999) gives the taxonomist no specific rules on how to name new species. Thus, unsurprisingly, many taxa have been named after famous scientists and celebrities, or mythological, biblical and pop-cultural characters (Jóźwiak, Rewicz $\&$ Pabis, 2015). These homages to celebrities often attract a lot of attention from social media. As far as spiders are concerned, taxonomists have been inspired by well-known literature characters and writers [e.g., The Jungle Book by Rudyard Kipling: Bagheera kiplingi (Saticidae) (Peckham \& Peckham, 1986); Harry Potter books by J. K. Rowling: the hat-looking spider Eriovixia gryffindori (Araneidae) (Ahmed, Khalap \& Sumukha, 2016); Orson Welles and William Shakespeare: Orsonwelles macbeth (Linyphiidae) (Hormiga 2002)], by actors, 
351

352

353

354

355

356

357

358

359

360

361

362

363

364

365

366

367

368

369

370

371

372

373

374

375

376

377

378

actress and movie characters [e.g., Angelina Jolie: the trapdoor spider Aptostichus angelinajolieae (Euctenizidae) (Bond \& Stockman, 2008); Terminator: Hortipes terminator (Corinnidae) (Bosselaers \& Jocqué, 2000); Predator and Arnold Schwarzenegger: Predatoroonops schwarzeneggeri (Oonopidae) (Brescovit et al., 2012)], and even by singers and progressive rock bands [e.g., Pink Floyd: long-jawed spiders in the genus Pinkfloydia (Tetragnathidae) (Dimitrov \& Hormiga, 2011); Johnny Cash: Aphonopelma johnnycashi (Theraphosidae) (Hamilton, Hendrixson, Bond, 2016); David Bowie: Heteropoda davidbowie (Sparassidae) (Jäger, 2008); Neil Young: Myrmekiaphila neilyoungi (Euctenizidae) (Bond \& Platnick, 2007)], among other examples. To date, the record for the spider genus with most species dedicated to celebrities goes to smiley-faced spiders Spintharus (Theridiidae). Recently, fifteen new species from the Caribbean region were named after very famous people who stood up for human rights and were committed to nature conservation, including David Attenbrough ( $S$. davidattenboroughi), Barack Obama and his wife ( $S$. barackobamai and S. michelleobamaae), David Bowie (S. davidbowiei), Leonardo $\mathrm{Di}$ Caprio (S. leonardodicaprioi) and Bernie Sanders (S. berniesandersi) (Agnarsson et al., 2017).

\section{Anatomy}

\section{Size}

(a) Largest living spiders - Theraphosa blondi (Latreille) (Theraphosidae) and Heteropoda maxima Jäger (Sparassidae). The Goliath bird-eater, T. blondi is possibly the largest known spider by mass. According to GWR (2017), a single reared individual reached a leg span of $28 \mathrm{~cm}$ and a weight of $170 \mathrm{~g}$. The giant huntsman spider, H. maxima (Sparassidae), discovered from caves in Laos, is possibly the largest known spider by leg span (up to $30 \mathrm{~cm}$; Jäger, 2001). With a total body length up to $39.7 \mathrm{~mm}$ and a leg span of over $10 \mathrm{~cm}$, females of 
Nephila komaci Kuntner \& Coddington (Araneidae) are the largest known orbweb spiders (Kuntner \& Coddington, 2009). (Figure 3a, 3b)

(b) Smallest adult female spider - Anapistula ataecina Cardoso \& Scharff (Symphytognathidae). The record for the smallest adult female spider goes to one specimen of the type series of $A$. ataecina, with a body length of $0.43 \mathrm{~mm}$. The species was discovered in the Frade cave system (Portugal); the male is still unknown (Cardoso \& Scharff, 2009).

(c) Smallest adult male spider - Patu digua Forster \& Platnick (Symphytognathidae). With a total length of about $0.37 \mathrm{~mm}$ (not including the chelicerae), $P$. digua is the smallest adult male spider ever described (Forster \& Platnick, 1977). Instead, the GWR (2017) reports the congeneric $P$. marplesi Forster as the smallest spider $(0.3 \mathrm{~mm})$. However, according to the original description, the male of $P$. marplesi has a prosoma length of $0.22 \mathrm{~mm}$, and an abdomen of $0.21 \mathrm{~mm}$ (Forster, 1959), in contrast to $0.15 \mathrm{~mm}$ and $0.25 \mathrm{~mm}$ (prosoma and abdomen, respectively) in $P$. digua (Forster \& Platnick, 1977). Intra-specific variability in the body size is possibly at the base of this discrepancy. It is also worth noticing, that there are other spiders of similar size for which only the female is described (see, e.g., "Smallest adult female spider").

(d) Most extreme sexual size dimorphism - Females weighing 125 times that of males. Sexual size dimorphism is a morphological syndrome in which conspecific male and female sizes differ significantly. Among terrestrial animals, the most extreme female-biased gigantism is found in orb weaving spiders (Foellmer \& Moya-Laraño 2007). Golden orb weaving spiders (Araneidae) are the most extremely sexually size dimorphic. Female on average can be up to 125 heavier than mating males (Kuntner et al., 2012). (Figure 3g)

(e) Most unusual sexual size dimorphism - Males larger than females. In most webbuilding spiders, females are larger than males (see "Most extreme sexual size dimorphism"). The water spider Argyroneta aquatica (Clerck) (Cybaeidae) (Figure $4 \mathrm{f}$ ) is one of the few spiders in which males are larger than females, possibly showing the most extreme male-biased sexual size dimorphism among 
spiders (Schütz \& Taborsky. 2003; 2005; Seymour \& Hetz, 2011). It has been suggested that larger males should have mobility advantages over smaller ones when moving under water (Schütz \& Taborsky. 2003). See also "Most bioluminescent" for an other case of unusual sexual dimorphism.

413

\section{Body Parts}

415 (a) Highest number of eyes - Eight. The highest number of eyes in spider is eight, as found in countless species. An anecdotic record is held by Troglohyphantes polyophthalmus Joseph (Linyphiidae), which possesses sixteen eyes according to the original description - as emphasized by the specific epithet (Joseph, 1881). However, this species was described on a specimen killed in the early stage of moulting, so that the number of eyes appeared doubled.

(b) Least number of eyes - Zero. The first eyeless spider ever described is Stalita taenaria Schiödte (Dysderidae) from the Postojnska cave in Slovenia (Schiödte, 1847). S. taenaria shares the record for the least number of eyes (zero) with more than 1,000 eyeless spider species inhabiting caves and other subterranean habitats around the world (Mammola \& Isaia, 2017). (Figure 3d)

(c) Largest eyes - Net-casting spiders, family Deinopidae. Net-casting spiders in the genus Deinopis possess extraordinary enlarged posterior median eyes (Blest \& Land, 1977), possibly the largest eyes of a spider (up to $1.4 \mathrm{~mm}$ in diameter; GWR, 2017). These eyes all possess large photoreceptors (20 $\mu \mathrm{m}$ wide, $110 \mu \mathrm{m}$ long; Land \& Nilsson, 2012), which are crucial for gathering light for nocturnal vision (see "Best nocturnal eyesight"). (Figure 3c)

(d) Longest relative chelicerae - Assassin spiders, family Archaeidae. Different spider species across many families exhibit chelicerae elongation, such as longjawed spiders (Tetragnathidae), long-jawed intertidal spiders (Desidae) and some jumping spiders (Salticidae). However, the highest ratio chelicerae/body size is possibly found in the Assassin spiders - also known as Pelican spiders. In many species, the length of the chelicerae almost equal the body length. Assassin spiders are cursorial hunters, specialized to feed upon other spiders. 
They are unique in their extreme modification of the cephalic area and jaws, giving them the appearance of a "neck" and "head" (e.g. Rix \& Harvey, 2011; Wood, Griswold \& Gillespie, 2012).

(e) Largest relative fangs - males of Myrmarachne, family Salticidae. In relation to their body size, the males of ant-mimicking spiders in the genus Myrmarachne (family Salticidae) not only have large chelicerae, but also extremely long fangs exceeding the length of the prosoma (see illustration in Millot, 1949a: p. 602, f. 369). The hypertrophy of the fangs is a male secondary sexual character, whereas females have normal fangs (Millot, 1949a).

(f) Longest relative walking legs - Unclear. Being the largest living spider by leg span, the giant huntsman spider Heteropoda maxima Jäger (Sparassidae) is most likely the species with the absolute longest walking legs (see "Largest living spiders"). However, if the length of the legs is relativized to the body length, probably the longest legs are found in the daddy long-legs spiders or house spiders (family Pholcidae) and in certain species of Ochyroceratidae (gen. Althepus and Leclercera). In species belonging to these groups, the length of the legs may be more then 5-7 times the body size (see Jocqué \& DippenaarSchoeman, 2006).

(g) Most legs - Ten. In insects, the expression domain of the Hox gene Antennapedia (Antp) controls the expression of legs. Khadjeh et al. (2012) used RNA inference to down-regulate this gene in the spider Achaearanea tepidariorum (C. L. Koch) (Araneae), giving rise to a 10-legged phenotype, which is, therefore, the spider with the highest number of legs.

(h) Most spinnerets - four pairs in Mesothelae. The spiders with the greatest number 464 of spinnerets are those belonging to the suborder Mesothelae (GWR, 2017), 465 which includes one living family (Liphistiidae) and a number of fossil representatives. They possess four pair of spinnerets, positioned in the middle of their segmented abdomen (Haupt, 2003). All other spiders possess from one to three pairs of spinnerets. 
(i) Longest relative spinnerets - Long-spinnered spiders, family Hersiliidae. Extremely elongated posterior spinnerets can be found in representative of the family Hersiliidae (see Jocqué \& Dippenaar-Schoeman, 2006). In certain species, they can be as long as the body of the spider (prosoma + opisthosoma). The enlarged anterior lateral spinnerets of Molycriinae (a subfamily of the longspinneret ground spiders Prodidomidae) are also remarkable being tube-like and extending throughout the whole opisthosoma (e.g. Platnick \& Baer, 2006).

\section{Internal organs}

a) Largest central nervous system - Very small spiders. The internal anatomy has been studied in details in very few species, and thus it is difficult to assess which species has the largest - or the smallest - central nervous system (CNS). Recent allometric studies of the gross neuroanatomy of a number of spider species, shown that very small spiders (including nymphal stages) have disproportionately larger CNSs relative to body mass when compared with largebodied forms. In fact, the brains of small spiders may extend out of their body cavity into their walking legs (coxae) (see Quesada et al., 2011: p. 526, f. 4). Accordingly, the relatively large CNS of very small spiders can occupies up to $78 \%$ of the cephalothorax volume (Quesada et al., 2011).

b) Largest relative venom glands - Filistatidae and Plectreuridae. Based on the comparative studies by Millot (1949b), two main venom gland organization can be distinguished - cylindrical and multilobular glands. Cylindrical glands can be short as in Mesothelae and most orthognath spiders, but can extend far into the prosoma as in most araneomorph spiders. According to the GWR (2017), the absolute largest venom glands are those of the wandering spiders of the South American genus Phoneutria (Ctenidae), measuring up to $10.4 \times 2.7 \mathrm{~mm}$ (see also "Most venomous to humans"). However, when considering the largest surface area relativized to body size, the multilobular glands reported for Filistatidae [Filistata insidiatrix (Forsskål)] and Plectreuridae (Plectreurys sp.) seems to be the most conspicuous (Millot, 1949b). For example, the large multilobular venom 
glands of $F$. insidiatrix occupy half of the prosoma as depicted by Millot (1949b: $\mathrm{f}$. 438).

c) Smallest relative venom glands - Mesothelae. The smallest venom gland (relative size) is reported from the most basal branching spider group, the Mesothelae. The gland of these ancient spiders extends only slightly behind the articulation of the fang and is very small and inconspicuous (Bristowe \& Millot, 1933; Foelix \& Erb, 2010). This might be also the reason why Mesothelae were thought to lack venom glands (e.g., Haupt, 2003). In fact, venom glands are part of the ground pattern of spiders and only in the family Uloboridae they are absent

\section{Physiology}

\section{Silk and webs}

511

a) Largest web (area) - 2.8 meters square. The Darwin's bark spider, Caerostris darwini Kuntner \& Agnarsson (Araneidae) spins a web whose surface ranges from 900 to $28,000 \mathrm{~cm}^{2}$. The largest measured web in this species was about 2.8 $\mathrm{m}^{2}$, being therefore the largest orb web ever measured (Kuntner \& Agnarsson, 2010; GWR, 2017). Prior to the discovery of this species, the record was held by representatives of the genus Nephila (Araneidae), capable of spinning orb webs of more than $1 \mathrm{~m}$ diameter (Kuntner \& Coddington, 2009). (Figure 3e, 3f)

$\beta)$ Largest web (length) - 25 meters. The anchor lines of the web of Darwin's bark spider, Caerostris darwini Kuntner \& Agnarsson (Araneidae), are capable of bridging over $25 \mathrm{~m}$, being the longest web among all spiders (Kuntner \& Agnarsson, 2010; Gregorič et al., 2011; GWR, 2017).

ұ) Smallest web - less than $10 \mathrm{~mm}$. The smallest spider webs are spun by representatives of the family Symphytognathidae (see "Smallest adult male spider" and "Smallest adult female spider"). According to estimations, in many species the webs can be less that $10 \mathrm{~mm}$ in diameter (GWR, 2017). 
8) Strongest silk - $520 \mathrm{MJ} / \mathrm{m}^{3}$. The Darwin's bark spider, Caerostris darwini Kuntner \& Agnarsson (Araneidae), produces the toughest known spider silk (GWR, 2017; see also "Largest web"). Tensile testing has shown that certain threads may reach the toughness of $520 \mathrm{MJ} / \mathrm{m}^{3}$ (average $\left.=350 \mathrm{MJ} / \mathrm{m}^{3}\right)$. The silk of $C$. darwini is therefore over 10 times tougher than Kevlar® (Agnarsson, Kuntner \& Blackledge, 2010; GWR, 2017). (Figure 3e)

ع) Strongest cocoon silk - Maximum stress $=0.64 \mathrm{GPa}$ and strain $=751 \%$. The record for the most stretchable egg sac silk goes to the stalk silk of the cocoon of Meta menardi (Latreille) (Tetragnathidae), for which tensile testing pointed out a maximum stress and strain of $0.64 \mathrm{GPa}$ and $751 \%$, respectively (Lepore et al., 2011). On the other hand, the toughness of the egg case silk threads recorded to date $\left(\mathrm{G}=193 \mathrm{MJm}^{-3}\right)$ is spun by the hermit spider Nephilengys cruentata (Fabricius) (Araneidae) (Alam et al., 2016).

\section{Venom}

a) Most venomous to humans - Australian funnel-web spiders, family Hexathelidae. In general, only few spider taxa are renowned for the efficacy of the venom, e.g. widow spiders (Latrodectus spp.; Theridiidae) causing latrodectism and recluse spiders (Loxosceles spp.; Sicariidae) causing severe skin lesions and systemic effects. Wandering spiders of the South American genus Phoneutria (Ctenidae) are known to be very poisonous by transferring large quantities of a strong neurotoxin during a single bite. However, it is important to emphasize that verified bites from other spider species cause only minor and transient effects (Vetter \& Isbister, 2008). Australian funnel-web spiders (family Hexathelidae) are considered to be the most dangerous spiders (to humans) in the world (White, 2000; Isbister et al., 2005). Within the family, the most venomous spider is possibly the Sydney funnel-web spider male, Atrax robustus O. PickardCambridge. In this species, just $0.2 \mathrm{mg} / \mathrm{kg}$ of the venom of the male is lethal for humans (GWR, 2017). On the other hand, according to literature reviews (Isbister et al., 2005), the tree-dwelling Australian funnel web spider Hadronyche cerberea 
556

557

558

559

560

561

562

563

564

565

566

567

568

569

570

571

572

573

574

575

576

577

578

579

580

581

582

583

584

585

L. Koch has the highest rate of severe envenomations (75\%), in contrast to $17 \%$ in $A$. robustus. Since the development of antidotes against funnel spider envenomation, no fatal bites have been reported (Nentwig \& Kuhn-Nentwig 2013b).

b) Least venomous - Shared by two families. Least venomous spiders are representative of the family Holarchaeidae and Uloboridae. Holarchaeidae entirely lacks openings of the poison glands (Kuhn-Nentwig, Stöcklin \& Nentwig, 2011; Nentwig \& Kuhn-Nentwig, 2013a), whereas Uloboridae entirely lack cheliceral venom glands (GWR, 2017). The latter have evolved an alternative hunting strategy: they wrap their prey in silk, cover it in regurgitated digestive enzymes and toxins and then ingest the liquified body (Weng, Barrantes \& Eberhard, 2006).

c) Most unusual venom - Spitting spiders, family Scytodidae. Spitting spiders produce the most unusual spider venom type. They have a domed cephalothorax that houses a large pair of glands, producing a mixture of venom and glue (Foelix, 2011). This mixture plays a crucial role in their unique prey capturing technique (see "Most creative hunting strategies"). The components expressed in the venom glands of one of the most common species of spitting spiders [Scytodes thoracica (Latreille)] have been recently identified by Zobel-Thropp et al. (2013). These include homologues of toxic proteins astacin metalloproteases, venom allergen, longistatin, and translationally controlled tumor protein.

\section{Sensory organs}

a) Best diurnal eyesight - Jumping spiders, family Salticidae. Despite the majority of spiders possess eight eyes, most species are known to have poor eyesight (Foelix, 2011). This is especially true in web-spinning spiders, relying mostly on vibrational cues for foraging and mating, rather than on visual perception. A notable exception is found in jumping spiders (Salticidae), being diurnal active ground dwellers renowned for their high performing visual system (e.g., Jackson \& Pollard, 1996; Zurek \& Nelson, 2012; Menda et al., 2014). They possess 
586

587

588

589

590

591

592

593

594

595

596

597

598

599

600

601

602

603

604

605

606

607

608

609

610

611

612

613

614

615

enlarged principal eyes which are specialized for resolution vision, functioning like moveable telescopes (Land, 1969). In addition, the three pairs of secondary eyes are highly sensitive to motion and collectively encompass a $360^{\circ}$ field of view (Duelli, 1978; Zurek et al., 2010; Zurek \& Nelson, 2012). Jumping spiders use this pronounced visual acuity in hunting and mating (see, e.g., "Most specialized prey classification", "Best hearing" and "Most elaborate courtship").

b) Best nocturnal eyesight - Net-casting spiders, family Deinopidae. The best nocturnal eyesight documented to date is found in the net-casting spiders (Deinopis spp.). They possess enlarged posterior median eyes (see also "Largest eyes") that are reported to be 2,000 times more sensitive to light than human eyes, thus appearing physiologically designed for detecting movement at night (Blest \& Land, 1977). It has been suggested that these visual cues are fundamental to net-casting spiders for capturing cursorial prey items (Stafstrom \& Hebets, 2016; see "Most creative hunting strategies"). (Figure 3c)

c) Best hearing - jumping spiders, family Salticidae. Shamble et al. (2016) recently presented behavioral and neurophysiological evidences about airborne sounds perception by jumping spiders. They reported that jumping spiders are able to perceive and respond to airborne acoustic stimuli, even at relatively large distances of about $3 \mathrm{~m}$. Behavioral experiments revealed that the jumping spider Phidippus audax Hertz is able to respond even to low-frequency sounds (around $80 \mathrm{~Hz}$ ). However, very few spider species have been tested in this respect.

d) Most bioluminescent - Cosmophasis umbratica Simon (Salticidae). The jumping spider C. umbratica, distributed from India to Indonesia (WSC, 2017), is the only known spider for which UV reflectance and the ability to see UV have been demonstrated experimentally ( $\mathrm{Lim} \& \mathrm{Li}, 2006 \mathrm{a}, \mathrm{b}$; GWR, 2017). This species is sexually dimorphic in the reflectance of ultraviolet (UV), with males having UVreflecting markings and females displaying UV-induced green fluorescence. The bioluminescence in this species is crucial for the success of mating (Lim, Land \& Li, 2007). 


\section{Biological cycle}

617

a) Longest life span - 40 years. In spiders, data about lifespan in the wild are extremely scarce. It was assumed that the enigmatic Tasmanian cave spider, Hickmania troglodytes, reaches a life-span of several decades (Doran et al. 1999). The greatest longevity documented is found in Theraphosidae in captivity, with certain species having a life expectancy of more than 30 years (data on Theraphosa and Aphonopelma; Schultz \& Schultz, 1999; Ibler et al., 2014; GWR, 2017).

b) Shortest circadian rhythm - 19 hours. Moore et al. (2016) recently described behavioral rhythms of locomotor activity and web building in the orb-weaving spider Cyclosa turbinata (Walckenaer) (Araneidae). They discovered that this species yield an exceptionally short-period clock, diverging from the natural 24-h light/dark cycle. In this species, the period of the free run is exceptionally short, about 19 hours.

\section{Eggs and sperm}

a) Longest sperm - $0.65 \mathrm{~mm}$. The longest known spider sperm by far is reported for the goblin spider Neoxyphinus termitophilus (Bristowe) (Oonopidae). With approximately $0.65 \mathrm{~mm}$, one sperm measures around $1 / 3$ of the body length of this spider (Lipke \& Michalik, 2015). The sperm is transferred coiled and encapsulated in groups resembling the so-called synspermia, which have a diameter of approximately $0.07 \mathrm{~mm}$ in this species. The longest transfer form $(0.08 \mathrm{~mm})$ is held by another goblin spider, Orchestina spp. (Lipke \& Michalik, 2015).

b) Highest number of eggs - >3,000. The number of eggs laid by spiders is highly variable depending on species and female body mass (Marshall \& Gittleman, 1994). Robinson \& Robinson (1976) reported more than 2,400 eggs for a species of Nephila (Araneidae). The same authors estimated that for other Nephila species one female may produce as many as 3,000 eggs in multiple egg 
645

646

647

648

649

650

651

652

653

654

655

656

657

658

659

660

661

662

663

664

665

666

667

668

669

670

671

672

673

674

sacs. According to available evidences, Nephila pilipes (Fabricius) is possibly the spider capable to lay the highest number of eggs per clutch. In this species, the egg sac usually contains more than 3,000 eggs (Higgins, 2002). Higgins observed how female fecundity (number of eggs laid per clutch) is a function of pre-laying female mass (see Higgins 2002: p. 382). The mass of the largest female sampled by Higgins was $6.9 \mathrm{~g}$ and so, it is possible to estimate that the clutch size of this female should be equivalent to 9,724 eggs. On the other hand, the GWR (2017) reports up to 3,000 eggs for a species apparently belonging to the genus Mygalomorphus, which is also deemed to lay the largest eggs (having the size of a small pea). However, despite being reported in a few websites, Mygalomorphus is neither a valid name nor a synonym in spider fossil (Dunlop, Penney \& Jekel, 2017) or extant (WSC, 2017) nomenclature.

c) Least number of eggs - One. The GWR (2017) currently reports Oonops domesticus Dalmas (Oonopidae) as the spider laying the fewest number of eggs, namely two eggs for each clutch. However, in Telema tenella (Simon) (Telemidae), a European cave-dwelling spider, the lowest number of eggs found in a single eggsac is one (Juberthie, 1985). The tendency to lay small numbers of eggs is a well-known adaptation to subterranean habitats. Studies on subterranean spiders are however scarce: it is likely that $T$. tenella may share this record with other cave species for which the number of eggs/cocoon was never quantified (Mammola \& Isaia, 2017).

\section{Behavior}

\section{Locomotion}

a) Best ballooners - Most spiders. Many spiders, especially small species or immature stages, disperse by releasing one or more silk threads to catch the wind (the so-called ballooning behavior). Airborne dispersal is particularly widespread amongst higher Entelegyne spiders (Bell et al., 2005). Distances travelled by spider ballooners can reach $>1,000 \mathrm{~km}$, as testified by sailors who reported spiders caught in their ships in the middle of oceans (Bell et al., 2005). 
Possibly, the longest distance covered with ballooning is $3,200 \mathrm{~km}$, as reported by Gressit (1965) for an unidentified linyphiid spider (Figure 4a).

677

b) Best sailors - Fishing spiders (Pisauridae). The ability to walk on water has evolved independently among over 1,200 species of vertebrates and invertebrates (Bush \& Hu, 2006). Spiders in many families are capable of locomotion on the surface of water (Suter, 2013). Most likely, the best sailors are the adults of fishing spiders Dolomedes spp. (Pisauridae), capable of moving across water surfaces taking advantage of wind currents (Suter, 1999). More recently, it was demonstrated that ballooning linyphiids and tetragnathids also display sailing-related behaviors, as specific responses to landing on water surfaces after ballooning (Hayashi et al., 2015; see also "Best ballooners"). (Figure 4b).

c) Fastest spider - Cebrennus rechenbergi Jäger (Sparassidae). The GWR (2017) reports the giant house spider Eratigena atrica (Koch) (Agelenidae) (formely known as Tegenaria gigantea) as the fastest spiders, having a maximum running speeds of $0.52 \mathrm{~m} / \mathrm{s}(1.9 \mathrm{~km} / \mathrm{h})$. However, the flic-flac behavior of the Maroccan flic-flac spider $C$. rechenbergi is possibly the fastest locomotory behavior documented for spiders [for a description see Jäger (2014: p. 350, f. 152-161)]. It was interpreted as a last resort escaping behavior, by which the speed of the spider can increase up to two times the normal running speed $(2 \mathrm{~m} / \mathrm{s}$ according to estimations). This striking locomotory behavior has also inspired the construction of a robot with similar motional elements (King, 2013).

d) Fastest rotational movement - Flattie spiders, genus Selenopsis. Flattie spiders are unique in their ability of performing rapid strike manoeuvres to capture prey approaching from an unlimited range of directions. This extraordinary ability, documented by Crews (2016) at the last International Congress of Arachnology, is crucial for the success of their ambush striking. By reaching an angular speed up to $120 \mathrm{~m} / \mathrm{s}$, they exhibit the fastest rotational movement in spiders.

703

\section{Foraging}


705

706

707

708

(a) Most creative hunting strategies - shared by different families. Spiders are extremely creative in terms of hunting strategies. In the course of their evolution, many spider species have developed impressive hunting strategies, and thus the decision of which one is the most effective is subjective. Some of the most unusual are:

- Bolas spiders (Araneidae, Mastophorini) have evolved a hunting strategy that combines chemical mimicry (mimics pheromone blends to attract the prey) with a bola-like weapon, which consist of a silk thread ending with a droplet of adhesive glue that the spider swing to catch its flying prey (Yeargan, 1994).

- Spitting spiders (Scytodes spp.), as their name suggest, have evolved a very peculiar hunting strategy to subdue prey: they spit a zig-zagged silken mixture of glue and venom to tether prey at a distance (see also "Most unusual venom"). Ejection velocities were measured as high as $28.8 \mathrm{~m} / \mathrm{s}$ (Suter \& Stratton, 2009).

- Net-Casting or Ogre Faced Spiders (Deinopis spp., Deinopidae) use their webs in a very unusual way. At night, net-casting spiders hang upside down, holding a rectangular capture silken snare, which is spun between their front legs. From this position, foraging spiders lunge towards prey, expanding the snare and actively entrapping aerial or terrestrial prey (Robinson \& Robinson, 1971; Stafstrom \& Hebets, 2016; see also "Best nocturnal eyesight" and Figure 3c)

- The orthognath purse-web spiders (Atypus spp.; Atypidae) creates a tube of silk that is hidden partially underground, with the portion above ground being covered in leaves and other debris. The spiders waits upside-down in the aerial part of their silk tubes and impale prey (mainly insects) crawling over the tube with their large thin fangs. Afterwards, the impaled prey is dragged into the tube and once eaten the remaining parts of the prey are ejected through the opening at the top of the tube (e.g., Enock, 1885; Bristowe, 1933). 
735

736

737

738

739

740

741

742

743

744

745

746

747

748

749

750

751

752

753

754

755

756

757

758

759

760

761

762

763

764

b) Fastest predatory strike - Zearchaea sp. (Mecysmaucheniidae). The fastest predatory strike in spiders was documented for trap-jaw spiders (family Mecysmaucheniidae). This family currently comprises 25 described species of tiny ground-dwelling spiders distributed in New Zealand and southern South America. Trap-jaw spiders rely on active hunting to prey capture. By means of high-speed video calculations, Wood et al. (2016) documented the speed of the power-amplified predatory strikes in 14 species belonging to this family. The fastest was a species in the genus Zearchaea, capable of striking with a speed of $0.00012 \mathrm{~s}$ and releasing a power output of $60,000 \mathrm{~W} / \mathrm{Kg}$ (mean values of 3 recording events).

c) Largest invertebrate prey - earthworms. The largest invertebrate prey reported for spiders are giant earthworms up to $1 \mathrm{~m}$ in length (Nyffeler et al., 2017). These were consumed by Theraphosa blondi (see "Largest living spiders")

d) Largest vertebrate prey - Fish, toads, birds, bats. Websites are full of stories and videos about spiders foraging on any kind of vertebrate animals. Although we acknowledge that some of them are truly impressive, we remain skeptical and rely on scientific literature. Accordingly, we report four scientifically documented cases of largest vertebrate prey:

- The largest fish captured by a spider is a goldfish Carassius auratus (Cyprinidae) of $\sim 9 \mathrm{~cm}$ length and presumably $15 \mathrm{~g}$ weight. It was captured by a pisaurid spider in a garden pond in Sydney. However, under the assumption that the largest wandering spider, the ctenid Ancylometes rufus (Walckenaer) weighing up to $7 \mathrm{~g}$, is as effective in overpowering oversized prey as the smaller-sized pisaurids, fish of up to $30 \mathrm{~g}$ might conceivably be killed in the wild (Nyffeler \& Pusey, 2014).

- The largest amphibians captured by spiders are possibly toads. Menin and colleagues (2005) reported the predation of an individual of Theraphosa blondi $(84.12 \mathrm{~mm}$ ) (see "Largest living spiders") on a juvenile Bufo marinus (Bufonidae) of $90.52 \mathrm{~mm}$ length (see also "Largest invertebrate prey"). 
765

766

767

768

769

770

771

772

773

774

775

776

777

778

779

780

781

782

783

784

785

786

787

788

789

790

791

792

793

794
- According to Brooks (2012), the largest bird found wrapped in a spider orb web is a laughing dove Streptopelia senegalensis (Columbidae) of $80 \mathrm{~g}$ (wing chord of $138 \mathrm{~mm}$ ).

- The largest bat found wrapped in a spider web is a Gould's wattled bat, Chalinolobus gouldii (Vespertilionidae), weighing around $15 \mathrm{~g}$ (estimated value). It was captured by an unidentified web-building spider (Nyffeler \& Knörnschild, 2013).

e) Strangest diet - Leaf tips. Spiders are renowned to be carnivorous. Being the only spider (mostly) herbivorous, Bagheera kiplingi Peckham \& Peckham (Saticidae), distributed from Mexico to Costa Rica, owns the record for the strangest diet. From behavioral observations and stable-isotope analysis, Meehan et al. (2009) showed that the diet of this spider predominantly comprises specialized leaf tips, the so-called Beltian food bodies. There are other spider species occasionally feeding on plant products (e.g. pollen), with at least 95 reports documented in literature (Nyffeler, Olson \& Symondson, 2016). (Figure 4g).

f) Fussiest spider - Evarcha culicivora Wesolowska \& Jackson (Salticidae). Prey specialization is uncommon in spiders (but see "Longest chelicerae" and "Strangest diet" for some examples). The jumping spider E. culicivora, reported from western Kenia (Wesolowska \& Jackson, 2003), is unique because it feeds indirectly on vertebrate blood by choosing blood-fed female mosquitoes (Anopheles) as prey (Jackson, Nelson \& Sune, 2005). Studies have shown that $E$. culicivora is able to discern between blood-fed mosquitoes from similar-sized prey that are not carrying blood, including congeneric male mosquitoes and females that have not fed (Jackson, Nelson \& Sune, 2005; Nelson \& Jackson, 2006, 2012). Stemming from these observations, it has been suggested that this peculiar species may be useful for the biological control of malaria vectors (Nelson \& Jackson, 2006). 
795

796

797

798

799

800

801

802

803

804

805

806

807

808

809

810

811

812

813

814

815

816

817

818

819

820

821

822

823

a) Shortest Mating - $<1$ second. Given the wealth of literature and observations, it is not easy to decide about the shortest mating. If we consider mating as an interaction between two partners, the shortest ones are possibly found in a number of wasp spiders (Argiope spp.), in the one-palped spider Tidarren argo Knoflach \& van Harten (Theridiidae) and in the dark fishing spider Dolomedes tenebrosus (Hentz) (Pisauridae). In fact, in these species, the male dies almost immediately after the insertion of his copulatory organ (spontaneous death) and is usually cannibalized by the female afterwards (Foellmer \& Fairbairn, 2003; Knoflach \& Van Harten, 2001; Schwartz, Wagner \& Hebets, 2013). (Figure 4c).

b) Longest mating - >18 hours. In certain species of Troglohyphantes spider (cave-dwelling Linyphiids), Deeleman-Reinhold (1978) observed a protracted mating lasting $>18$ hours. However, due to the paucity of information, it seems likely that longer mating durations could be expected in other species. (Figure 4d)

c) Best date - Nuptial gifts in Pisaura mirabilis (Clerck) (Pisauridae). "Nuptial gifts" are nutrients that males of a number of species (especially Arthropods) offer to females prior to, during, or shortly after copulation (Gwynne, 2008). In spiders, nuptial gifts have been documented in various forms as e.g. glandular secretion or wrapped prey items. Possibly, the most spectacular nuptial gift is reported for $P$. mirabilis (e.g., Van Hasselt, 1884; but see Itakura, 1993 for a possible other species), as it consists of large prey items wrapped up in silk by the male (Prokop \& Maxwell, 2012) - but males may sometime 'cheat' by offering worthless gifts in term of nutrient content, e.g. by inflating their gifts with inedible items or excessive silk (Ghislandi et al., 2017). The male offers his nuptial gift during courtship and, while the female is feeding on it, he successfully mates with her. It has been suggested that the female's hunger state is thus decisive for mating success, as hungry females are more likely to accept a nuptial gift and hence to copulate (Bilde et al., 2007). 
824

825

826

827

828

829

830

831

832

833

834

835

836

837

838

839

840

841

842

843

844

845

846

847

848

849

850

851

852

853

d) Most elaborate courtship - Jumping spiders, family Salticidae. With a certain degree of subjectivity, the mating dance of peacock spiders Maratus spp. (Salticidae), can be listed among the most elaborate and beautiful courtship displays in arthropods (Girard, Kasumovic \& Elias, 2011). Such "spider dance" recently received great attention in the social media - the videos about the courtship displays of different species of Maratus in the Peacockspiderman YouTube channel had cumulatively more than 12 million views as of June 2, 2017. (Figure 4e)

e) Most complex song - Jumping spiders in the Habronattus coeacatus group. During courtship, these spiders use complex multimodal signals made up of combinations of motion displays and vibratory songs. The latter are extremely complex, as they consist of up to 20 elements organized in functional groupings (motifs) that change as courtship progresses (Elias et al., 2012), thus possibly representing the most complex songs documented in spiders.

f) Loudest spider - Maratus michaelseni (Simon) (Salticidae). Sound production by spiders has been documented in at least 26 families. Sounds are produced either by stridulation (friction of two body parts), or percussion (striking of the substratum). Sounds are used in at least three behavioral contexts: courtship, defense against predators and aggressive interactions between males (Uetz \& Stratton, 1982). In certain species, sounds produced by spiders are even audible to the human ear, such as the one produced by Anyphaena accentuata (Walckenaer) (Anyphaenidae) and Gladicosa gulosa (Walckenaer) (Lycosidae) (GWR, 2017). To our knowledge, the loudest spider sound is produced by the males of the jumping spider Maratus michaelseni (Simon) (Araneae: Salticidae). During courtship, this species produce sounds by stridulation, which can be heard several meters away (Gwynne \& Dadour, 1985; see also "Most elaborate courtship").

g) Best mother - matriphagy. Providing offspring with food is thought to be the most important form of parental care. Possibly, the most 'unusual and extreme form of care' (Evans, Wallis \& Elgar, 1995) is called matriphagy, in which the 
854

855

856

857

858

859

860

861

862

863

864

865

866

867

868

869

870

871

872

873

874

875

876

877

878

879

880

881

882 mother sacrifices herself to feed her offspring. This peculiar form of parental care has evolved at least in six spider families (Schneider, 1996).

h) Best father - Dolomedes tenebrosus (Hentz, 1844) (Pisauridae). In numerous spiders, females eat their mating partner just after the copula (see "Shortest Mating"). Such self-sacrifice is evolutionary advantageous if being eaten sufficiently increases offspring number or fitness (paternal effort hypothesis) or, either, the fertilization success. Recent experiments conducted by Schwartz, Wagner \& Hebets (2016) on the dark fishing spider, D. tenebrosus, demonstrated an impact of male consumption on offspring size and overall survival indicating that self-sacrifice behavior should be adaptive.

\section{Lifestyle}

a) Most peaceful - Social spiders. The vast majority of spiders conduct a solitary lifestyle, and generally display an aggressive behavior even toward conspecifics. However, a small number of species have evolved different forms of group living lifestyles (Lubin \& Bilde, 2007; see also “Largest colony"). Two main forms of sociality has arisen in spiders: i) cooperative species ("social" sensu Lubin \& Bilde, 2007) live in family group territories wherein they share communal nests and capture webs, which they inhabit together, cooperating in foraging and raising young; ii) colonial species (territorial permanent social" sensu Avilés, 1997) occur in aggregations, but individuals in the colony generally forage and feed alone and there is no maternal care beyond the egg stage. Among these two group living styles, the first is rare, being found in at least six families: Agelenidae, Dictynidae, Eresidae, Oxyopidae, Theridiidae, Thomisidae (Lubin \& Bilde, 2007). On the other hand, coloniality is more common, being reported in at least 12 families (Whitehouse \& Lubin, 2005). However, if considering pseices names, the record holders would be either Singafrotypa mandela Kuntner \& Hormiga (Araneidae) and Stasimopus mandelai Hendrixson \& Bond (Ctenizidae) or Bristowia gandhii 
883

884

885

886

887

888

889

890

891

892

893

894

895

896

897

898

899

900

901

902

903

904

905

906

907

908

909

910

911

912

(Salticidae) and Pimoa gandhii (Pimoidae), dedicated to the Nobel Peace Prizes Nelson Mandela and Mohandas Karamchand Ghandi.

b) Largest colony - Anelosimus eximius (Keyserling) (Theridiidae). Among social spiders (see "Most peaceful"), A. eximius forms the largest cooperative groups (GWR, 2017). This species is found in rainforest in Central and South America. Communal webs may range in length from $10-25 \mathrm{~cm}$ containing only few individuals, to 2-3 $\mathrm{m}$ or more containing up to thousands of individuals (Smith, 1986). According to press media release ("Meet the spiders that have formed armies 50,000 strong" BBC - earth. Online at: www.bbc.com), some of the colonies may reach more than $7 \mathrm{~m}$, containing as many as 50,000 individual spiders. However, it has been suggested that natural selection should actually favor intermediate rather than large colony sizes (Avilés \& Tufino, 1998).

c) Best thieves - Kleptoparasites. In spiders, best thieves are kleptoparasites, i.e. spiders regularly stealing food from the web of other spider species. Kleptoparasites generally do not build webs, but exploit other spiders' web for any of their activity. To date, kleptoparasitism has been documented in five spider families - Theridiidae, Dictynidae, Salticidae, Symphytognathidae and Mysmenidae (Vollrath, 1987). (Figure 4h)

d) Best camouflage - Shared by many species. In the course of their evolution, many spider species have developed mimicry impressively (Pekar, 2014), and thus it is almost impossible to decide upon the best mimetic species. Spiders are able to mimic inanimate objects (masquerading mimicry), unpalatable or undesirable food in the eyes of their predators (Batesian mimicry), some of the habitat features in which they dwell (crypsis) or even specific pheromones produced by their prey (see "Most creative hunting strategies"). Examples of astonishing mimicries are found in spiders resembling bird dropping [e.g. Cyclosa ginnaga Yaginuma (Araenidae) (see, e.g., Liu et al., 2014)], ants [e.g. numerous species of Salticids and Thomisids (Cushing, 2012)], toads [e.g. Poecilopachys australasia (Griffith \& Pidgeon) (Araneidae) (Vink, 2015)], 
913

914

915

916

917

918

919

920

921

922

923

924

925

926

927

928

929

930

931

932

933

934

935

936

937

938

939

940

941

942

seeds and fallen flowers [e.g. Arachnura spp. (Araneidae)] and leafs [e.g. Poltys sp. (Araneidae) (Kuntner et al., 2016)]. A very peculiar case of selfmimicry is given by Cyclosa mulmeinensis (Araneidae), which confound potential predators and parasitoids by attaching web decorations made by prey pellets that mimic its own body shape (Tseng \& Tso, 2009).

e) Longest time under water - >16 hours. With the exception of Argyroneta aquatica, which conduct a wholly aquatic life (see "Strangest habitat"), there are other species that are able to conduct a partially aquatic life in intertidal habitats (see, also, "Longest time under water in a nest"). Using certain species of wolf spiders (Lycosidae), Pétillon, Montaigne \& Renault (2009) compared survival rate during both a submersion and a recovery period after submersion. They found that salt-marsh species Arctosa fulvolineata (Lucas) was able to survive for more than 16 hours underwater $(100 \%$ mortality obtained at 36 hours). This extraordinary survival was possible due to the spider ability to fall into a hypoxic coma, a physiological adaptation to overcome tidal inundation under water.

f) Longest time under water in a nest - up to 19 days. Desis marina (Hector) (Desidae) inhabits intertidal rocky habitats in New Caledonia and New Zealand (WSC, 2017). In these habitats, the species sometimes needs to survive up to 19 days of tide-induced submergence (McQueen \& McLay, 1983). Despite lacking specific respiratory adaptations, $D$. marina is able to hide away inside bull kelp holdfasts or sea worm burrows on the shore, blocking the water out with a lid woven of silk (Rovner, 1986; GWR, 2017).

\section{Ecology}

\section{Habitat}

a) Highest altitude - >6,000 meters. Euophrys omnisuperstes Wanless (Salticidae) owns the record of the spider dwelling at the highest altitude. A male specimen was collected at an altitude of around 5,900 $\mathrm{m}$ a.s.l. during an expedition in Mount Makalu (Nepal/China). Immature specimens collected by Major Kingston 
943

944

945

946

947

948

949

950

951

952

953

954

955

956

957

958

959

960

961

962

963

964

965

966

967

968

969

970

971

972

at an altitude of around 6,700 $\mathrm{m}$ in Mount Everest (Nepal/China) were tentatively attributed to the same species (Wanless, 1975).

b) Lowest altitude - $-418 \mathrm{~m}$ below sea level. The Dead Sea (Palestine, Israel and Jordan), is the lowest point on dry land $-418 \mathrm{~m}$ below sea level. In their checklist of spiders from Israel, Zonstein \& Marusik (2013) reported 39 species occurring in this area, with representatives of the families Agelenidae, Araneidae, Cithaeronidae, Filistatidae, Gnaphosidae, Lycosidae, Oxyopidae, Prodidomidae, Salticidae, Scytodidae, Theridiidae and Thomisidae. Seven species have their own type locality (i.e. the locality where the species has been described) on the shore of the Dead Sea: Pterotricha engediensis Levy and Talanites fervidus Simon (Gnaphosidae), Halodromus patellidens (Levy) (Philodromidae), Enoplognatha deserta Levy \& Amitai and Theridion vallisalinarum Levy \& Amitai (Theridiidae), Ozyptila rigida (O. Pickard-Cambridge) (Thomisidae), and Pax engediensis Levy (Zodariidae).

c) Coldest place inhabited by spiders - Oymyakon (Russia). The town of Oymyakon in Eastern Yakutia (Russia, $64.5^{\circ} \mathrm{N}-142.5^{\circ} \mathrm{E}$ ) is known to be the coldest inhabited area of the planet, with an absolute minimal temperature of $-71.2^{\circ} \mathrm{C}$ recorded in 1924. Marusik, Koponen \& Potapova (2008) documented the presence of 55 spider species living in Oymyakon and surroundings, including representatives of 11 families, mostly boreal or hypoarctic species of Gnaphosidae, Lycosidae and Linyphiidae.

d) Hottest place inhabited by spiders - Death Valley, Inyo, California. The highest ground temperature on Earth $\left(56.7^{\circ} \mathrm{C}\right)$ was measured at Furnace Creek, Death Valley (CA) (Kubecka, 2001). A few authors (e.g., Crews \& Hedin, 2006; Crew \& Gillespie, 2014) reported about spiders living in this area, including wolf spiders (Lycosidae), mesh-web weavers (Dictynidae), jumping spiders (Salticidae), crab spiders (Thomisidae), cellar spiders (Pholcidae) and sand spiders (Homalonychidae). A few of them are exclusively found in very hot and salty areas and are considered true extremophiles. These are the wolf spider Pardosa saltona Dondale \& Redner, the jumping spider Habronattus tarsalis (Banks), and 
973

974

975

976

977

978

979

980

981

982

983

984

985

986

987

988

989

990

991

992

993

994

995

996

997

998

999

1000

1001

1002

1003

the salt flat specialist Saltonia incerta (Banks) (Sarah Crews, personal communication 2017).

e) Northernmost species - Erigone psychrophila Thorell (Linyphiidae). Arctic spiders are reported from very high latitudes, including: Devon and Ellesmere Island (northern Canada) at $74-76^{\circ} \mathrm{N}$; Greenland at $70-84^{\circ} \mathrm{N}$; Iceland at $64-66^{\circ}$ $\mathrm{N}$; Jan Mayen Land at $71^{\circ} \mathrm{N}$; Bear Island at $79^{\circ} \mathrm{N}$; Svalbaard at $78^{\circ} \mathrm{N}$; Novaya Zemlya at $71^{\circ} \mathrm{N}$; Franz Josef Archipelago at 80-81 $\mathrm{N}$ (Pugh et al., 2004). Among these, the northernmost documented record is possibly the linyphiid $E$. psycrophila. It was collected during a scientific expedition by Mr. Henry Fisher at Cape Flora, Northbrook Island (Franz Joseph Arcipelago, Barents Sea) at $80^{\circ} \mathrm{N}$, and later published by Pickard-Cambridge (1898).

f) Southernmost species - Alien species in continental Antarctic. Native spiders are absent from both Continental and Maritime Antarctica, the southernmost regions of the world. However, spider records from continental Antarctic exist, all representing dead, anthropogenically imported, exotic or 'alien' contaminants. These Antarctic aliens are Erigone autumnalis Emerton, one unidentified 'Micryphantidae' (Linyphiidae) and an unidentified 'Attidae' (Salticidae) from the Ross Sea coast of Continental Antarctica. Instead, the southernmost live records are from South Georgia ( $54^{\circ} \mathrm{S}$; 8 species, 3 of them alien) and Macquarie Island ( $54^{\circ} \mathrm{S} ; 7$ species, 2 of them aliens), yet Neotropical species occur slightly further south at Tierra del Fuego (54-56 S) (Pugh 2004).

g) Most diverse habitat - Atlantic forest. The highest continental biodiversity on Earth is found in Brazil (Brandon et al. 2005), the largest tropical country in the world. This country present a variety of terrestrial ecosystems, including one of the major global biodiversity hotspot, the Atlantic Forest (Myers et al. 2000). For this biome, Brescovit \& Santos (2017) provided the observed value of 1,672 species of spiders and estimated the impressive number of $2,714-3,816$ species living therein. The highest species richness in the Atlantic Forest has also been reported for other taxa, such as flowering plants (Sobral \& Stehmann, 2009), flatworms (Carbayo et al., 2008), dragonflies (De Marco \& Vianna, 2005), and springtails (Culik \& Zeppelini-Filho, 2003). 
1004

1005

1006

1007

1008

1009

1010

1011

1012

1013

1014

1015

1016

1017

1018

1019

1020

1021

1022

1023

1024

1025

1026

1027

1028

1029

1030

1031

1032

1033

h) Least suitable habitat - Marine water. No spiders evolved the ability to inhabit permanently submerged marine habitats, making it the most unsuitable habitat for spiders (but see "Longest time underwater" and "Longest time underwater in a nest"). The so-called sea spiders (Pycnogonida) are a very remote ancestor group of the Arachnids, but despite the name, it is wrong to consider them spiders. Although being traditionally classified as chelicerates, some features of this peculiar marine group suggest that they may be representatives of the earliest arthropods from which the Arachnids evolved (Dunlop, 2010).

i) Strangest habitat - Underwater. Spiders are well-known to be ubiquitous in terrestrial ecosystem (Foelix, 2011). Being the only known spiders living a wholly aquatic life, we consider the diving bell spider Argyroneta aquatica (Clerck) (Cybaeidae) the species inhabiting the most peculiar habitat. A. aquatica has specific adaptations to breathe in immersion, being therefore able to hunt, to consume prey, to moult, to deposit eggs and to copulate underwater (e.g., Seymour \& Hetz, 2011; Mammola, Cavalcante \& Isaia, 2016). (Figure 4f).

\section{Conservation}

a) Rarest - Unclear. In lack of detailed information about biology, ecology, range of distribution, and population size of the different species, rarity is extremely difficult to define from a biological viewpoint (Gaston, 1994). It is therefore challenging to assess which is the rarest spider species in the world. For instance, the WSC (2017) propose as the rarest spider the Kauai cave wolf spider (Adelocosa anops Gertsch), occurring in a few caves in the island of Kauai (covering a surface of circa $10.5 \mathrm{~km}^{2}$ ). Smithers \& Whitehouse (2016) suggested Nothophantes horridus Merrett \& Stivens (Linyphiidae) as the rarest spider in the world, being recorded exclusively from two abandoned limestone quarries near Plymouth, covering a surface of circa $0.1 \mathrm{~km}^{2}$ (Cardoso \& Hilton-Taylor, 2015). However, the reputation of 'rarest spiders' is possibly shared by numerous spiders described on the base of a single specimen, and never recorded thereafter (see WSC, 2017). 
1034

1035

1036

1037

1038

1039

1040

1041

1042

1043

1044

1045

1046

1047

1048

1049

1050

1051

1052

1053

1054

1055

1056

1057

1058

1059

1060

1061

1062

b) Most endangered - Shared by 36 species. Thirty-six species of spiders are listed in the 'critically endangered' IUCN category (IUCN, 2015), being therefore the most endangered species of spiders. Habitat changes and deterioration represent the major threats for these species. Some endangered Theraphosidae are also frequently commercialized as pets (see "Most wanted as pet"). However, it is worth noticing that only a minor part of the extant spider species has been evaluated against IUCN criteria (Cardoso et al., 2011) - currently 199 out of $\sim 47,000$ extant species (IUCN, 2017).

c) Most wanted as pet - Tarantulas. As far as we are aware, the Gooty sapphire Poecilotheria metallica Pocock (Theraphosidae) is among the most commercialized spider species. According to IUCN (2017), P. metallica is considered 'critically endangered', not only for the degradation of its natural habitat, but also due to its indiscriminate collection by pet traders. Since 2002 , reports of advertised $P$. metallica exported illegally from India and put on sale on the internet have been documented (Molur, Daniel \& Siliwal, 2016).

\section{Curiosities}

a) The longest journey - Into space. In 1973, two females of Araneus diadematus Clerck (Araneidae) were sent into space on the Skylab 3 mission to the US Skylab space station (Witt et al., 1976). They are the first spiders that travelled in space (GWR, 2017). Witt et al. (1976) observed that web spun in space had modified features such as unusual distribution of radial angles and low number of turning points, which were attributed to the effect of the absence of gravity.

b) Most delicious - Personal preference. It is difficult to assess which is the most delicious species of spider, as flavour is rather subjective and a matter of gourmets (see also "Most eaten by humans"). It is worth noting, however, that in some countries, spiders are considered a food delicacy. As an example, in Cambodia and Thailand Haplopelma albostriatum (Simon) (Theraphosidae) is served fried - but also canned with salt - as street food (Ray, 2002). A few 
species in Thailand are also used to flavour vodka and whiskey. In Venezuela, the jungle tribe Piaroa commonly eat Theraphosa blondi roasted.

c) Most eaten by humans - Many. Most likely, the most eaten spiders are eaten accidentally. In many countries, the legal limits governing the presence of arthropods in processed foods are indeed large enough so that over time a large amount of spider parts is ingested (see, e.g., CFSAN, 1998).

d) Most feared - Indiscriminate. Countless species of spiders terrify the public alike. With a prevalence rate ranging from 3.5 to $6.1 \%$ of the population (Jacobi, 2004; Schmitt \& Müri, 2009), "arachnophobia" is indeed documented to be the most common phobia related to animals (Hofmann, Alpers \& Pauli, 2009).

e) Largest item of clothing woven from spider silk - A lady's cape. The American fashion designer Nicholas Godley and textile expert Simon Peers masterminded and created the largest item of clothing woven from spider silk: a lady's cape with matching 4-m long brocade scarf containing ca. $1.5 \mathrm{~kg}$ of silk. The silk used was woven by more than on million females of Nephila (Araneidae) (GWR, 2017).

f) Most iconic spider - Spiderman. Arachnid symbolism is found through human history (Melic, 2002). Possibly, the most famous, successful and iconic character inspired by arachnids is Spiderman, the famous Marvel superhero created by Stan Lee and Steve Ditko in 1962 - see the official Guinness World Records for a number of records related to Spiderman. However, it is worth noticing that according to a recent survey (Da-Silva et al., 2014) Arachnids inspired at least 123 other comics' characters in the Comics literature. 


\section{DISCUSSION}

1088 Spiders have a bad reputation among the general public (Jacobi, 2004; Schmitt \& Müri, 1089 2009): they are considered ugly, hairy, brown, and deadly poisonous creatures. There 1090 are tales describing how they lay eggs in human skin, frequent toilet seats in airports, 1091 and crawl into your mouth when you are sleeping. Misinformation about spiders in the 1092 popular media and on the World Wide Web is often rampant, leading to distorted 1093 perceptions and negative feelings about spiders. However, despite their negative 1094 connotation, spiders offer intrigue and mystery and can be used to effectively engage 1095 even arachnophobic people into arachnid-based discussions and activities. Towards 1096 this end, this original list of record breaking spider achievements provides a wide range 1097 of entry points into the rich biology of spiders. The numerous facts, observations, and even unknowns compiled herein (99 records) offer intriguing content and inspiration for educators, provide engaging hooks for students and learners of all ages, and highlight potentially fruitful new directions for future scientific research. Given the scarcity of database such as this, our work can provide a framework and foundation to which others can contribute.

For the scholars among us, whose interests encompass the history of science, we reveal in our section on Arachnology and Arachnologists that scientists have been interested in spiders since the early 1700 s. In reading these early published works, their predominantly descriptive nature and focus on natural history is notable and is found to contrast strongly with the style of current primary scientific publications. Despite the shift 1108 of focus and style, however, scientists today remain fascinated by spiders. Fortunately, 1109 the number of arachnologists and the diversity of arachnological studies do not appear 1110 to be diminishing. The largest congress of arachnologist in history, for example, was as

1111 recent as 2016. We expect that arachnology will remain strong and hope that this

1112 contribution will help to draw future arachnologists into the world of spider research.

1113 In the section on Paleontology, we anticipate that the extensive evolutionary 1114 history of spiders is also notable to educators. In contrast to the vertebrate groups, that 1115 are often at the forefront of one's mind when discussing "animals" [e.g. mammals, Late 1116 triassic, 237 -201 Myr ago (Benton, 2005); birds, ca. 70 Myr ago (Prum et al., 2015)], 1117 spiders have inhabited our planet for at least 300 million years. Interesting, however, we 
1118 show that the earliest recorded spider silk dates back to $\sim 140 \mathrm{Myr}$ ago. Readers might 1119 wonder - why is there such a discrepancy between the timing of spider fossils and silk 1120 records? We suggest that such a question could facilitate further research into the 1121 process of fossilization and the preservation of different biological materials. 1122 Additionally, armed with the knowledge that spiders have multiple silk glands and can 1123 produce different types of silk with distinct physical properties, readers might now 1124 wonder - what type(s) of silk was present $140 \mathrm{Myr}$ ago? Did spiders always build 1125 webs, or did webs evolve more recently? Again, such questions could motivate further 1126 research among interested students. From this additional research, they could learn that 1127 the earliest spiders did not build webs and, in fact, the vertical orientation of the orb 1128 webs did not evolve until insects took the air in flight (Bond \& Opell, 1998). Thus, the 1129 history of spider silk use provides an appealing and accessible storyline for teaching 1130 about evolutionary change. Indeed, one arachnid-based informal science event, that 1131 has successfully travelled to multiple venues across the United States of America, 1132 incorporates silk-related games and activities to demonstrate both the diversity and 1133 evolutionary history of spider silk form and function (Eight-Legged Encounters; 1134 http://hebetslab.unl.edu/eight-legged-encounters/spiders-and-silk/).

1135 The Taxonomy and Systematics section provides baseline information and facts 1136 regarding the biodiversity of spiders. From reading this section, one might wonder why 1137 jumping spiders, in particular, are the most diverse spider family. In another section 1138 (Physiology - Sensory organs) readers learn that jumping spiders also have the best 1139 diurnal eyesight among all spiders. They are also cited as having the most elaborate 1140 courtship (Behavior - Reproduction). Is there a relationship then between visual 1141 capacity, courtship behavior, and diversification? Curiously, the other spider family with 1142 good diurnal eyesight - wolf spiders (Lycosidae) - are also fairly diverse $(>2,000$ 1143 species; WSC, 2017) and some genera within this family are also known for their 1144 complex courtship displays [e.g. Schizocosa (Hebets et al., 2013); Pardosa (Chiarle \& 1145 Isaia, 2013)]. Research attempting to understand the potential relationship(s) between 1146 diversification (i.e. species number), visual capacity, and reproductive behavior could 1147 provide important insights into our understanding of speciation - e.g. the putative role 1148 of sensory physiology. 
1149 Our sections on Anatomy are meant to follow the basic spider body structure that 1150 we presented in the section Brief Introduction to Spiders. The first prominent records 1151 highlight the incredible size range of spiders, with the largest spiders measuring almost $115240 \mathrm{~mm}$ in length and the smallest less than $0.4 \mathrm{~mm}$. This size range represents a 1153 hundred-fold difference between the largest and smallest spiders. Do these spiders 1154 have similar lifespans? Do they go through a similar number of molts? If so, are there 1155 fundamental differences in their metabolic rate or other aspects of their physiology that 1156 can account for observable differences in growth and development? To the best of our 1157 knowledge, these are still open questions.

1158 In our anatomy section we also present records associated with measurable body 1159 parts and appendages - e.g. chelicerae, walking legs. Though the records in this 1160 section should be straightforward and uncontroversial, we found them to be difficult to 1161 ascertain in many instances. For example, to be informative and useful towards our 1162 goals, structural records need to be related to overall body size - e.g. largest legs 1163 relative to body size. Not only are most published size measurements not calculated in 1164 relation to body size, but published numbers also tend to be buried in very old species 1165 descriptions. We maintain, however, that such information on anatomical relative size 1166 could be incredibly informative for both teaching evolutionary concepts, and for guiding 1167 future research efforts.

1168 Species with particularly long fangs, for example, likely have a unique foraging 1169 strategy or prey type - e.g. the unusual shapes of the chelicerae and fangs of spiders 1170 in the family Dysderidae are often specializations for feeding on woodlice (Cooke, 1965;

1171 Řezáč \& Pekar, 2007). Unusually large or atypically shaped spinnerets may indicate 1172 something original about the way in which silk is laid or produced, or may reflect novel 1173 aspects of the silk itself. As such, spiders with unusual spinnerets may be fruitful focal 1174 taxa for studies of web structure and design or silk production and composition. 1175 Similarly, species with particularly long legs relative to their body may provide good 1176 focal taxa for exploring mechanisms underlying locomotion, the findings of which could 1177 potentially stimulate new designs in robotics. We encourage arachnologists to examine 1178 our current external anatomy records for peculiarities that might deserve further focused 1179 attention, but also to be diligent about incorporating basic measurement information in 
1180 future publications, such that new records can be readily found and documented.

$1181 \quad$ Our Internal organs section (Anatomy) is admittedly the sparsest and incorporates

1182 the most speculation. This is due to the fact that documentation and assessment of

1183 variation in internal anatomical structures is not typical of scientific studies, unless there

1184 is a very specific research question associated with the data collection. Regardless, this

1185 section remains important as it highlights additional area(s) where opportunities for

1186 discovery may exist. Which is the spider with the largest relative heart? Why? Unusually

1187 large, or small, hearts could suggest physiological challenges and/or adaptations

1188 related to respiration and circulation. A priori, it is impossible to foresee how knowledge

1189 of such adaptations might be useful or informative - e.g. for innovation related to

1190 human health. Some of our documented records in this section highlight the potential

1191 importance of internal anatomical records. For example, we include records

1192 demonstrating that small spiders have proportionally large brains that take up an

1193 impressive portion of their body cavity (Quesada et al., 2011). This observation raises

1194 fundamental questions about the constraints that small animals may face in terms of

1195 brain size and associated behavior. This record breaking achievement can also be used

1196 to guide students through fundamental information regarding cell biology and nervous

1197 system form and function. It can, for example, guide students through asking and

1198 answering fundamental questions such as: How variable in size are animal cells? Why?

1199 Are all axons within and/or among animals of similar diameter? Is there an upper or

1200 lower limit to axon diameter? Ultimately, while we have certainly provided a starting

1201 point for internal anatomical records, we urge scientists to pay closer attention to

1202 variation in internal anatomy both within and among spider species, as we see this as a

1203 particularly fruitful area of future research inspiration and discovery.

1204 Many animal physiologists adopt the Krogh principle (1929), which states that "for

1205 such a large number of problems there will be some animal of choice, or a few such

1206 animals, on which it can be most conveniently studied". We expand on this principle by

1207 proposing that the problems do not need to exist a priori, but instead animals

1208 themselves can present problems or puzzles for us to study. For example, in our

1209 Physiology section, we highlight the shortest circadian rhythm recorded. This new

1210 research raises a number of questions. What is the circadian rhythm of most spiders? 
1211 How and why might circadian rhythms vary within and across taxonomic groups?

1212 Similarly, it is in this section that we highlight new research documenting the capacity of

1213 a jumping spider to perceive airborne sound. Though there is evidence of hearing in this

1214 jumping spider (Shamble et al., 2016), the mechanism underlying this capacity remains

1215 enigmatic, thus opening up new avenues for future research. Many of our other

1216 documented record breaking achievements can guide students through a range of

1217 questions: how do animals tolerate extreme environments? Why doesn't the blood of

1218 spiders freeze in the winter? Or, how might fundamental knowledge of animal sensory

1219 systems inspire technological innovation - e.g. the development of new microphones

1220 based on the biology of spider vibratory senses (Kang et al., 2014).

1221 Our compilation of behavioral and ecological record breaking achievements were

1222 two of the easier sections to pull together and can likely be expanded upon greatly in

1223 the future. The behavioral diversity of spiders has been leveraged by ethologists for

1224 centuries, and syntheses and compilations of this rich repertoire already exist (e.g.,

1225 Herberstein, 2011). Due to their range of reproductive behavior and mating systems,

1226 foraging strategies, communication systems, and lifestyles (among others), spiders

1227 provide excellent models for teaching and learning about behavioral evolution

1228 (Herberstein \& Hebets, 2013). Their ethology has already facilitated research on a

1229 range of topics from sexual selection (e.g., Huber, 2005) to sperm dynamics (e.g.,

1230 Herberstein et al., 2011), and there are seemingly unlimited possibilities for the future.

1231 Furthermore, we pointed out the extreme ecological plasticity of this successful

1232 group of Arthropods. They reach more than $6,000 \mathrm{~m}$ altitude, they survive in the hottest

1233 and coldest places on Earth, they colonize almost all types of ecosystems - one

1234 exception, marine underwater - and exhibit extraordinary values of diversity, especially

1235 in the Tropics. Furthermore, being mostly predators (but see "Strangest diet") they play

1236 a fundamental role in the ecosystem. Despite their ecological importance, the

1237 conservation issues about this animal group is largely neglected (Rix et al., 2016). In

1238 fact, the extinction risk of a very minimal portion of the known spider diversity has been

1239 assessed (see "Most endangered"). However, global threats such as habitat loss,

1240 fragmentation and climate change are likely to affect the survival of a vast number

1241 species inhabiting a range of different habitats (Leroy et al., 2011; 2013; Kuntner et al., 
1242 2013; Mammola, Goodacre \& Isaia, 2017).

1243 It is notable that many of our incorporated records have been published since

1244 2010. This accurately reflects the relative infancy of arachnology relative to other

1245 organismal systems such as mammals, birds, or even insects. By some estimates, 1246 arachnologists have described only one third of the spider species worldwide 1247 (Agnarsson, Coddington \& Kuntner, 2013); and even among the described species, 1248 basic information about their biology and natural history remain unknown. Indeed, our 1249 knowledge of spiders is still in its early stages and, with the expected future discoveries 1250 of thousands of new species and novel observations of species already known to 1251 science, will surely come new records and new curiosities. We also acknowledge that 1252 our list of record breaking achievements is far from exhaustive and it is certainly 1253 possible that records hidden in old publications or written in inaccessible languages (to 1254 us) may have been missed.

1255 In summary, with their incredible diversity, spiders provide outstanding examples 1256 of how increased knowledge, understanding, and appreciation of a specific group of 1257 organisms can facilitate learning and understanding of science and nature, increase the 1258 public's enthusiasm for and connection with the natural world, and simultaneously push 1259 the envelope of science forward in a number of distinct directions. We hope that this 1260 compilation of record breaking achievements helps spiders to achieve their teaching, 1261 learning, and research potential. We also documented some discrepancies between the 1262 information found in the scientific literature and those in the official Guinness World 1263 Records database (GWR, 2017), thus we are able to provide suggestions for updates 1264 and corrections (see Supplementary materials 1). Finally, in order to transform this 1265 database into a community-driven knowledge base, we will implement these records on 1266 the website of the International Society of Arachnology (www.arachnology.org). We very 1267 much see this as a living document that will grow and change as new knowledge is 1268 gained and new discoveries are made.

\section{ACKNOWLEDGMENTS}

1271 Many thanks to all friends and colleagues who posed to us bizarre questions about 1272 spiders, stimulating the idea for this paper. Rebecca Wilson, Yael Lubin, Yuri Marusik, 
1273 Theo Blick, Jens Runge, Philippe Vernon, Filippo Milano, Alexandra Jones, Sarah 1274 Crews, Raquel Galindo, Colton Watts, Rowan McGinley, Noori Choi, Alissa Anderson, 1275 Cecilia Ruffino, and Silvia Grilli provided information and/or suggested some of the 1276 records listed herein. We thank Irene Frigo for the help in creating the layout of figure 1. 1277 We are grateful to all photographers for sharing their photos of spiders (see captions of 1278 figures 2-4). Special thanks is due to Sergio Henriques and two anonymous referees 1279 for useful comments and suggestions to improve the manuscript.

1280

\section{SUPPORTING INFORMATION}

\section{Supplementary materials 1}

1283 Comments to the official biological record held by spiders as listed in the Guinness 1284 World Records database (www.guinnessworldrecords.com).

Agnarsson I, Kuntner M, Blackledge TA (2010) Bioprospecting finds the toughest biological material: extraordinary silk from a giant riverine orb spider. PLOS ONE 5(9):e11234. doi: 10.1371/journal.pone.0011234

Agnarsson I, Coddington JA, Kuntner M (2013) Systematics—progress in the study of spider diversity and evolution. In: Penney D, ed. Spider research in the 21st century: trends and perspectives. Manchester: Siri Scientific Press, 58-111. from Central Western Ghats, India (Araneae: Araneidae). Indian Journal of Arachnology 5(1-2):2427. doi:10.5281/zenodo. 208960 
1303 Alam P, Otieno D, Nuhamunada M, Anyango R, Odoyo J, Odhiambo J, Onyango K (2016) The toughest recorded spider egg case silks are woven into composites with tear-resistant architectures. Materials Science and Engineering: C 69:195-199. doi:10.1016/j.msec.2016.06.063

Alfred J, Baldwin IT (2015) The natural history of model organisms: new opportunities at the wild frontier. Elife 4:e06956. doi:10.7554/eLife.06956.001

Andersen T, Baranov V, Hagenlund LK, Ivković M, Kvifte GM, Pavlek M (2016) Blind flight? A new troglobiotic Orthoclad (Diptera, Chironomidae) from the Lukina Jama-Trojama Cave in Croatia. PLoS ONE 11(4):e0152884. doi:10.1371/journal.pone.0152884

Avilés L (1997) Causes and consequences of cooperation and permanent-sociality in spiders. In Crespi B Press, 476-498.

Avilés L, Tufino P (1998) Colony size and individual fitness in the social spider Anelosimus eximius. The American Naturalist 152(3):403-418.

Babb PL, Lahens NF, Correa-Garhwal SM, Nicholson DN, Kim EJ, Hogenesch JB, Kuntner M, Higgins L, Hayashi CY, Agnarsson I, Voight BF (2017) The Nephila clavipes genome highlights the diversity of spider silk genes and their complex expression. Nature Genetics 49(6):895-903. doi:10.1038/ng.3852

Bell JR, Bohan DA, Shaw EM, Weyman GS (2005) Ballooning dispersal using silk: world fauna, phylogenies, genetics and models. Bulletin of entomological research 95(02):69-114.

Bilde T, Tuni C, Elsayed R, Pekar S, Toft S (2007) Nuptial gifts of male spiders: sensory exploitation of the female's maternal care instinct or foraging motivation?. Animal Behaviour 73(2):267-273. doi:10.1016/j.anbehav.2006.05.014 
1334 Blest AD, Land MF (1977) The physiological optics of Dinopis subrufus L. Koch: a fish-lens in a spider.

1335

1336

1337

1338

1339

1340

1341

1342

1343

1344 1345

1346

1347

1348

1350

1351

1352

1353

1354

1355

1356

1357

1358

1359

1360

1361

1362

1363

1364

1365

Proceedings of the Royal Society of London B: Biological Sciences 196(1123): 197-222. doi:10.1098/rspb.1977.0037

Bode F, Sachs F, Franz MR (2001) Tarantula peptide inhibits atrial fibrillation. Nature 409(6816):35-36. doi: $10.1038 / 35051165$

Bonabeau E, Dorigo M, Theraulaz G (2000) Inspiration for optimization from social insect behaviour. Nature 406(6791):39-42. doi:10.1038/35017500

Bond JE, Opell BD (1998) Testing adaptive radiation and key innovation hypotheses in spiders. Evolution 52(2):403-414. doi.org/10.1206/0003-0082(2007)3596[1:ATROTT]2.0.CO;2

Bond JE, Platnick NI (2007) A taxonomic review of the trapdoor spider genus Myrmekiaphila (Araneae, Mygalomorphae, Cyrtaucheniidae). American Museum Novitates 3596: 1-30. doi:10.1206/00030082

Bond JE, Stockman AK (2008) An integrative method for delimiting cohesion species: finding the population-species interface in a group of californian trapdoor spiders with extreme genetic divergence and geographic structuring. Systematic Biology 57(4): 628-646. doi: $10.1080 / 10635150802302443$

Bonnet P (1955) Bibliographia araneorum. Toulouse 2(1):1-918.

Bonnet P (1956) Bibliographia araneorum. Toulouse 2(2):919-1926.

Bonnet P (1957) Bibliographia araneorum. Toulouse 2(3):1927-3026.

Bonnet P (1958) Bibliographia araneorum. Toulouse 2(4):3027-4230.

Bonnet P (1959) Bibliographia araneorum. Toulouse 2(5):4231-5058. 
1366 Bosselaers J, Jocqué R (2000) Hortipes, a huge genus of tiny afrotropical spiders (Araneae, Liocranidae.). Bulletin of the American Museum of Natural History 256:4-108. doi:10.1206/00030090

1369

1370

Brandon K, da Fonseca GAB, Rylands AB, da Silva JMC (2005) Brazilian conservation: challenges and opportunities. Conservation Biology 19:595-600. doi:10.1111/j.1523-1739.2005.00710

Brasier M, Cotton L, Yenney I (2009) First report of amber with spider webs and microbial inclusions from the earliest Cretaceous (c. $140 \mathrm{Ma}$ ) of Hastings, Sussex. Journal of the Geological Society 166(6):989-997.

Breene RG, Allen Dean D, Edwards GB, Hebert B, Levi HV, Manning G, McWest K, Sorkin L (2003) Common Names of Arachnids (5th Edition). American Arachnological Society. ISBN 1-929427-11-5

Brescovit AD, Bonaldo AB, Santos AJ, Ott R, Rheims CA (2012) The Brazilian goblin spiders of the new genus Predatoroonops (Araneae, Oonopidae). Bulletin of the American Museum of Natural History 370:1-68. doi:10.1206/766.1

Bristowe WS (1933) Notes on the biology of spiders. IX. The British species of Atypus. Annals and Magazine of Natural History 11(10):289-302.

1386

Benton MJ (2005) Vertebrate Palaeontology (3rd ed). Blackwell Publishing, Oxford.

Brignoli PM (1983) A catalogue of the Araneae described between 1940 and 1981. Manchester University Press.

Bristowe WS, Mollot J (1933) The liphistiid spiders. With an appendix on their internal anatomy by J. Millot. Proceedings of the Zoological Society of London 102(4):1015-1057.

Brooks DM (2012) Birds caught in spider webs: a synthesis of patterns. The Wilson Journal of Ornithology 124(2):345-353. doi:10.1676/11-148.1

Bush JW, Hu DL (2006) Walking on water: biolocomotion at the interface. Annual Review of Fluid Mechanics 38, 339-369. doi:10.1146/annurev.fluid. 38.050304 
1401 Carbayo F, Froehlich M, Bettio A, Universit C (2008) Estado do conhecimento dos macroturbelários (Platyhelminthes) do Brasil. Biota Neotropica 8:177-197

1403

1404 Cardoso P, Hilton-Taylor C (2015) Nothophantes horridus. The IUCN Red List of Threatened Species 2015: e.T70560176A7056021. doi:10.2305/IUCN.UK.2015- 1.RLTS.T70560176A70560214.en

Cardoso P, Scharff N (2009) First record of the spider family Symphytognathidae in Europe and description of Anapistula ataecina sp. n. (Araneae). Zootaxa 2246:45-57. doi:10.5281/zenodo.190697

1410

1411 Cardoso P, Silva I, de Oliveira NG, Serrano AR (2004) Indicator taxa of spider (Araneae) diversity and their efficiency in conservation. Biological Conservation 120(4): 517-524. doi:10.1016/j.biocon.2004.03.024

1414

1415 Cardoso P, Borges PV, Triantis K, Ferrández M, Martín J (2011) Adapting the IUCN Red List criteria for invertebrates. Biological Conservation 144(10):2432-2440. doi:10.1016/j.biocon.2011.06.020

1418 Carwardine M (2008) Animal records. New York, Sterling

CFSAN_Center for Food Safety and Applied Nutrition (1998) The food defect action levels: levels of natural or unavoidable defects in foods that present no health hazards for humans. U.S. Department of Agriculture. Online at: http://vm.cfsan.fda.gov/ dms/dalbook.html. Accessed: 13 April 2016.

Chiarle A, Isaia M (2013) Signal complexity and modular organization of the courtship behaviors of two sibling species of wolf spiders (Araneae: Lycosidae). Behavioral processes 97:33-40. doi:10.1016/j.beproc.2013.04.004 arter beskrefne och med illuminerade figurer uplyste. Stockholmiae. 
1432 Cooke, J. A. L. (1965) Spider genus Dysdera (Araneae, Dysderidae). Nature 205:1027-1028. 1433 doi:10.1038/2051027b0

1434

1435 Crew SC (2016) Extreme striking in Selenops (Araneae: Selenopidae). 20 ${ }^{\text {th }}$ International Congress of Arachnology, Golden, Colorado. Denver Museum of Natural History \& Science report 3:72.

Crews SC, Gillespie RG (2014) Desert salt flats as oases for the spider Saltonia incerta Banks (Araneae: Dictynidae). Ecology and evolution 4(19):3861-3874. doi: 10.1002/ece3.1242

Crews SC, Hedin M (2006) Studies of morphological and molecular phylogenetic divergence in spiders (Araneae: Homalonychus) from the American southwest, including divergence along the Baja California Peninsula. Molecular phylogenetics and evolution 38(2):470-487. doi:10.1016/j.ympev.2005.11.010

Culik MP, Zeppelini-Filho D (2003) Diversity and distribution of Collembola (Arthropoda: Hexapoda) of Brazil. Biodiversity and Conservation 12:1119-1143. doi:10.1023/A:1023069912619

Cushing PE (2012) Spider-ant associations: an updated review of myrmecomorphy, myrmecophily, and myrmecophagy in spiders. Psyche: A Journal of Entomology 2012:151989.

Da-Silva ER, Coelho LBN, Campos TRM, Carelli A, Miranda GS, Santos ELS, Silva TBNR, Passos MIS (2014) Marvel and DC characters inspired by arachnids. The Comics Grid: Journal of Comics

De Marco P, Vianna DM Jr (2005) Distribuição do esforço de coleta de Odonata no Brasil - subsídios para escolha de áreas prioritárias para levantamentos faunísticos. Lundiana 6:13-26.

Deeleman-Reinhold CL (1978) Revision of the cave-dwelling and related spiders of the genus Troglohyphantes Joseph (Linyphiidae), with special reference to the Jugoslav species. Opera Academia Scientiarum et Artium Slovenica (Classis IV) Ljubljana 23(6):1-221. 
1465 Dimitrov D, Hormiga G (2011) An extraordinary new genus of spiders from Western Australia with an 1466 expanded hypothesis on the phylogeny of Tetragnathidae (Araneae). Zoological Journal of the 1467 Linnean Society 161(4):735-768. doi:10.1111/j.1096-3642.2010.00662

1468

Doran NE, Kiernan K, Swain R, Richardson AMM (1999) Hickmania troglodytes, the Tasmanian cave spider, and its potential role in cave management. Journal of Insect Conservation 3:257-262. doi:10.1023/A:1009677531343

Duelli P (1978) Movement detection in the posterolateral eyes of jumping spiders (Evarcha arcuata, Salticidae). Journal of Comparative Physiology A: Neuroethology, Sensory, Neural, and Behavioral Physiology 124(1):15-26. doi:10.1007/BF00656387

1476

Dunlop JA (2010) Geological history and phylogeny of Chelicerata. Arthropod structure \& development 39(2):124-142. doi: 10.1016/j.asd.2010.01.003

Dunlop JA, Penney D, Jekel D (2017) A summary list of fossil spiders and their relatives. In World Spider Catalog. Natural History Museum Bern, online at http://wsc.nmbe.ch, version 18.5, accessed on 06 October 2017

Edwards J, Whitaker D, Klionsky S, Laskowski MJ (2005) A record-breaking pollen catapult. Nature 435:164. doi:10.1038/435164a

Elias DO, Maddison WP, Peckmezian C, Girard MB, Mason AC (2012) Orchestrating the score: complex multimodal courtship in the Habronattus coecatus group of Habronattus jumping spiders (Araneae: Salticidae). Biological Journal of the Linnean Society 105(3): 522-547. doi:10.1111/j.10958312.2011.01817

1492 Enock F (1885) The life-history of Atypus piceus Sulz. Transaction of the Entomological Society of 1493 London:389-420. doi:10.1038/376299a0 
1498 Fleischner TL, Espinoza RE, Gerrish GA, Greene HW, Kimmerer RW, Lacey EA, Pace S, Parrish JK, 1499 Swain HM, Trombulak SC, Weisberg S, Winkler DW, Zander L (2017) Teaching biology in the field: importance, challenges, and solutions. BioScience 67(6):558-567. doi:10.1093/biosci/bix036

1502 Foelix RF (2011) Biology of Spiders (3 $3^{\text {rd }}$ ed.). Oxford University Press, New York.

1503

1504 Foelix R, Erb B (2010) Mesothelae have venom glands. Journal of Arachnology 38(3): 596-598. doi:10.1636/B10-30.1

1506

Foellmer MW, Fairbairn DJ (2003) Spontaneous male death during copulation in an orb-weaving spider. Proceedings of the Royal Society of London B: Biological Sciences 270(2):183-185. doi:10.1098/rsbl.2003.0042

1510

Foellmer MW, Moya-Laraño J (2007) Sexual size dimorphism in spiders: patterns and processes. In: Sex, size and gender roles: Evolutionary studies of sexual size dimorphism. In: Fairbairn DJ, Blanckenhorn WU, Szekely T, ed.). Oxford University Press, New York, 71-81.

Forster RR (1959) The spiders of the family Symphytognathidae. Transactions and Proceedings of the Royal Society of New Zealand 86:269-329.

1517

Forster RR, Platnick NI (1977) A review of the spider family Symphytognathidae (Arachnida, Araneae). American Museum Novitates 2619:1-29.

Garrison NL, Rodriguez J, Agnarsson I, Coddington JA, Griswold CE, Hamilton CA, Hedin M, Kocot KM, Ledford JM, Bond JE (2016) Spider phylogenomics: untangling the Spider Tree of Life. PeerJ 4:e1719. doi:10.7717/peerj.1719

Gaston KJ (1994) Rarity. Chapman and Hall, London.

1528 Ghislandi PG, Beyer M, Velado P, Tuni C (2017) Silk wrapping of nuptial gifts aids cheating behaviour in 1529 male spiders. Behavioral Ecology 28(3):744-749. doi:10.1093/beheco/arx028 
1531 Girard MB, Kasumovic MM, Elias DO (2011) Multi-codal courtship in the peacock spider, Maratus volans (O.P.-Cambridge, 1874). PLoS ONE 6(9):e25390. doi:10.1371/journal.pone.0025390

1534 Glaw F, Köhler J, Townsend TM, Vences M (2012) Rivaling the world's smallest reptiles: Discovery of miniaturized and microendemic new species of leaf chameleons (Brookesia) from northern Madagascar. PLoS ONE 7(2):e31314. doi:10.1371/journal.pone.0031314

Greene HW (2005) Organisms in nature as a central focus for biology. Trends in Ecology \& Evolution 20(1):23-27. doi:10.1016/j.tree.2004.11.005

1540

Gregorič M, Agnarsson I, Blackledge TA, Kuntner M (2011) How did the spider cross the river? Behavioral adaptations for river-bridging webs in Caerostris darwini (Araneae: Araneidae). PLoS

1544

Gressitt JL (1965) Biogeography and ecology of land arthropods of Antarctica. In: van Miegham J, van Oye P, ed. Biology and ecology of Anarctica. Monographiae Biologicae 15. W. Holland, Junk, 431490.

1548

Griswold CE, Audisio T, Ledford JM (2012) An extraordinary new family of spiders from caves in the Pacific Northwest (Araneae, Trogloraptoridae, new family). ZooKeys 215:77-102.

Grzybowski BA, Huck WT (2016) The nanotechnology of life-inspired systems. Nature nanotechnology 11(7):585-592. doi:10.1038/NNANO.2016.116

1555

1556

Guinness World Records_-GWR (2017) The Guinness World Records. Online at: http://www.guinnessworldrecords.com. Accessed: 4 October 2017 
1559 Guthold R, Cowan MJ, Autenrieth CS, Kann L, Riley LM (2010) Physical activity and sedentary behavior among schoolchildren: a 34-country comparison. The Journal of pediatrics 157(1):43-49. doi:10.1016/j.jpeds.2010.01.019

1562

1563 Gwynne DT (2008) Sexual conflict over nuptial gifts in insects. Annual Review of Entomology 53:83-101. doi:10.1146/annurev.ento.53.103106.093423

1565

Gwynne DT, Dadour IR (1985) A new mechanism of sound production by courting male jumping spiders (Araneae: Salticidae, Saitis michaelseni Simon). Journal of Zoology 207(1):35-42.

1568

1569

Hallal PC, Andersen LB, Bull FC, Guthold R, Haskell W, Ekelund U, Lancet Physical Activity Series Working Group (2012) Global physical activity levels: surveillance progress, pitfalls, and prospects. The Lancet 380(9838):247-257. doi:10.1016/S0140-6736(12)60646-1

1572

Hamilton CA, Hendrixson BE, Bond JE (2016) Taxonomic revision of the tarantula genus Aphonopelma Pocock, 1901 (Araneae, Mygalomorphae, Theraphosidae) within the United States. ZooKeys 560:1-340. doi:10.3897/zookeys.560.6264

Haupt J (2003) The Mesothelae - a monograph of an exceptional group of spiders (Araneae: Mesothelae). Zoologica 154:1-102.

Hayashi M, Bakkali M, Hyde A, Goodacre SL (2015) Sail or sink: novel behavioral adaptations on water in aerially dispersing species. BMC evolutionary biology 15(1):118. doi:10.1186/s12862-015-0402-5

1582

1583 Heard SB (2014) On whimsy, jokes, and beauty: can scientific writing be enjoyed?. Ideas in Ecology and Evolution 7(1):7: 64-72. doi:10.4033/iee.2014.7.14.f evolution of signal complexity in the multimodal courtship displays of Schizocosa wolf spiders. 
1590 Heim M, Keerl D, Scheibel T (2009) Spider silk: from soluble protein to extraordinary fiber. Angewandte Chemie International Edition 48(20):3584-3596. doi:10.1002/anie.200803341

1592

Herbestein ME (2011) Spider Behavior: Flexibility and Versatility. Cambridge University press, Cambridge. dol:10.1017/CBO9780511974496

Herberstein ME, Hebets EA (2013) Why are spiders good models for behavioral research. In: Penney D, ed. Spider research in the 21st century: trends and perspectives. Manchester: Siri Scientific Press, 230-251.

Herberstein ME, Schneider JM, Uhl G, Michalik P (2011) Sperm dynamics in spiders. Behavioral Ecology 22(4):692-695. doi:10.1093/beheco/arr053

Higgins L (2002) Female gigantism in a New Guinea population of the spider Nephila maculata. Oikos 99(2):377-385. doi.10.1034/j.1600-0706.2002.990220

Hillyard PD (1994) The book of the spider: from arachnophobia to the love of spiders. Random House Incorporated.

1608

Hinman MB, Jones JA, Lewis RV. (2000) Synthetic spider silk: a modular fiber. Trends in biotechnology 18(9):374-379. doi:10.1016/S0167-7799(00)01481-5

1611

1612

Hofmann SG, Alpers GW, Pauli P (2009) Phenomenology of panic disorder, social anxiety disorder, and specific phobia. In: Antony MM, Stein MB, Ed. Oxford handbook of anxiety and related disorders.

1615

Hormiga G (2002) Orsonwelles, a new genus of giant linyphiid spiders (Araneae) from the Hawaiian Islands. Invertebrate Systematics 16:369-448. doi:10.1071/IT01026

1618

1619

Huber BA (2005) Sexual selection research on spiders: progress and biases. Biological Reviews 80(3), 363-385. doi:10.1017/S1464793104006700 
1625

1626

1627

1628

1629

1630

1631

1632

1633

1634

1635

1636

1637

1638

1639

1640

1641

1642

1643

164

1645

1646

1647

1648

1649

1650

1651

1652 Jäger P (2001) A new species of Heteropoda (Araneae: Sparassidae: Heteropodinae) from Laos — the 1653 largest huntsman spider? Zoosystema 23:461-465.

International Human Genome Sequencing Consortium (2004) Finishing the euchromatic sequence of the human genome. Nature 431(7011): 931-45.

Isbister G, Gray M, Balit C, Raven R, Stokes B, Porges K, Turner E, White J, Fisher M (2005) Funnel-web spider bite: a systematic review of recorded clinical cases. Medical journal of Australia 182(8):407411.

Itakura Y (1993) The life history and nuptial feeding of a nursery web spider, Pisaura lama.

Insectarium 30:88-93.

IUCN (2015) The IUCN Red List of Threatened Species (Version 2015-4). Online at: www.iucnredlist.org. Accessed 14 May 2016

Jacobi F, Wittchen H-U, Hölting C, Höfler M, Pfister H, Müller N, Lieb R (2004) Prevalence, co-morbidity and correlates of mental disorders in the general population: results from the German Health Interview and Examination Survey (GHS). Psychological Medicine 34, 597-611. doi:10.1017/S0033291703001399

Jackson RR, Pollard SD (1996) Predatory behavior of jumping spiders. Annual review of entomology 41(1): 287-308. doi:10.1146/annurev.en.41.010196.001443

Jackson RR, Nelson XJ, Sune GO (2005) A spider that feeds indirectly on vertebrate blood by choosing female mosquitoes as prey. Proceedings of National Academy of Science USA 102:15155-15160. doi:10.1073/pnas.0507398102 
1655 Jäger P (2008). Revision of the huntsman spider genus Heteropoda Latreille 1804: species with exceptional male palpal conformations from southeast Asia and Australia (Arachnida, Araneae: Sparassidae: Heteropodinae). Senckenbergiana Biologica 88:239-310.

1658

1659

Jäger P (2014) Cebrennus Simon, 1880 (Araneae: Sparassidae): a revisionary up-date with the description of four new species and an updated identification key for all species. Zootaxa 3790(2):319-356. doi:10.11646/zootaxa.3790.2.4

1662

1663 Jocqué, R. and Dippenaar-Schoeman, A. (2006) Spider Families of the World. Royal Museum for Central Africa, Tervuren.

1665

Joseph G (1881) Erfahrgungen im wissenschaftlichen Sammeln und Beobachten der den Krainer Tropfsteingrotten eigenen Arthropoden. Berliner Entomologische Zeitschrift 25:233-282.

1668

1669

Jóźwiak P, Rewicz T, Pabis K (2015) Taxonomic etymology-in search of inspiration. ZooKeys 513:143160. doi: $10.3897 /$ zookeys.513.9873

1671

1672

Juberthie C (1985) Cycle vital de Telema tenella dans la Grotte-Laboratoire de Moulis et strategies de reproduction chez les Araignees cavernicoles. Memoires de Biospéologie 12(7):77-89.

1674

1675

Kang D, Pikhitsa PV, Choi YW, Lee C, Shin SS, Piao L, Park B, Suh K-Y, Kim T, Choi M (2014) Ultrasensitive mechanical crack-based sensor inspired by the spider sensory system. Nature 516(7530):222-226. doi:10.1038/nature14002

1678 Divergent role of the Hox gene Antennapedia in spiders is responsible for the convergent evolution of abdominal limb repression. Proceedings of the National Academy of Sciences 109(13):49214926. doi:10.1073/pnas.1116421109

1683

1684

King GF, Hardy MC (2013) Spider-venom peptides: structure, pharmacology, and potential for control of insect pests. Annual review of entomology 58:475-496. doi:10.1146/annurev-ento-120811-153650

1686 
1687 King RS (2013) BiLBIQ: a biologically inspired robot with walking and rolling locomotion. (2 ${ }^{\text {nd }}$ Volume). Springer, Verlag, Berlin, Heidelberg. doi:10.1007/978-3-642-34682-8

1689

1690 Klug C, De Baets K, Kröger B, Bell MA, Korn D, Payne JL (2015) Normal giants? Temporal and latitudinal shifts of Palaeozoic marine invertebrate gigantism and global change. Lethaia 48(2):267-288. doi:10.1111/let.12104

1693

1694 Knight AJ (2008) "Bats, snakes and spiders, Oh my!" How aesthetic and negativistic attitudes, and other concepts predict support for species protection. Journal of Environmental Psychology 28(1):94-103. doi:10.1016/j.jenvp.2007.10.001

1697

Knoflach B, Harten A (2001) Tidarren argo sp. nov. (Araneae: Theridiidae) and its exceptional copulatory behavior: emasculation, male palpal organ as a mating plug and sexual cannibalism. Journal of Zoology 254(4):449-459. doi:10.1017/S0952836901000954

1701

Kraus O (1999) Historic overview of past congresses of arachnology and of the Centre International de Documentation Arachnologique (C.I.D.A.). Journal of Arachnology 27: 3-6.

1704

Krogh A (1929) The progress of physiology. Amewrican Journal of Physiology 90:243-251.

1706

Kubecka P (2001) A possible world record maximum natural ground surface temperature. Weather 56(7):218-221. doi:10.1002/j.1477-8696.2001.tb06577

1709

Kuhn-Nentwig L, Stöcklin R, Nentwig W (2011) Venom composition and strategies in spiders: is everything possible? Advances in Insect Physiology 40:1-86. doi:10.1016/B978-0-12-387668$3.00001-5$

Kundmann JC (1737) Rariora naturae et artis, item in re medica, oder Seltenheiten der Natur und Kunst des Kundmannischen Naturalien Cabinets, wie auch in der Artzeney-Wissenschaft. Breslau \&

1718 Kuntner M, Coddington JA (2009) Discovery of the largest orbweaving spider species: the evolution of gigantism in Nephila. PLoS ONE 4(10):e7516. doi:10.1371/journal.pone.0007516 
1721 Kuntner M, Agnarsson I (2010) Web gigantism in Darwin's bark spider, a new species from Madagascar (Araneidae: Caerostris). Journal of Arachnology 38(2):346-356. doi:10.1636/B09-113.1

1723

1724 Kuntner M, Gregorič M, Cheng RC, Li D (2016) Leaf masquerade in an orb web spider. Journal of Arachnology 44(3), 397-400.

1726

1727 Kuntner M, Năpăruş M, Li D, Coddington JA (2014) Phylogeny predicts future habitat shifts due to climate 1728 change. PloS one, 9(6), e98907. doi:10.1371/journal.pone.0098907

1729

Kuntner M, Zhang S, Gregorič M, Li D (2012) Nephila female gigantism attained through post-maturity molting. Journal of Arachnology 40(3):345-347. doi:10.1636/B12-03.1

1732

Land MF (1969) Movements of the retinae of jumping spiders (Salticidae: Dendryphantinae) in response to visual stimuli. Journal of experimental biology 51(2):471-493.

1735

Land MF, Nilsson D-E (2012) Animal eyes. Oxford University Press.

1737

1738

Lepore E, Marchioro A, Isaia M, Buehler MJ, Pugno NM (2012) Evidence of the most stretchable egg sac silk stalk, of the European Spider of the Year Meta menardi. PLoS ONE 7(2):e30500. doi:10.1371/journal.pone.0030500

1741

1742

1743

Leroy B, Bellard C, Dubos N, Colliot A, Vasseur M, Courtial C, Bakkenes M, Canard A, Ysnel F (2014) Forecasted climate and land use changes, and protected areas: The contrasting case of spiders.

1745

1746

Leroy B, Paschetta M, Canard A, Bakkenes M, Isaia M, \& Ysnel F (2013) First assessment of effects of Diversity and Distributions, 20:686-697. doi:10.1111/ddi.12191 global change on threatened spiders: Potential impacts on Dolomedes plantarius (Clerck) and its conservation plans. Biological conservation, 161:155-163. doi.org/10.1016/j.biocon.2013.03.022 
1750 Linnaeus, C (1758) Systema naturæ per regna tria naturæ, secundum classes, ordines, genera, species, cum characteribus, differentiis, synonymis, locis. Tomus I, Editio decima, reformata, Holmiae.

1752

1753 Lipke E, Michalik P (2015) Evolutionary morphology of the male reproductive system and spermatozoa of 1754 goblin spiders (Oonopidae, Araneae). Bulletin of the American Museum of Natural History 906:172. doi:10.1206/906.1

1756

1757

Lim MLM, Li D (2006a) Behavioural evidence of UV sensitivity in jumping spiders (Araneae: Salticidae). Journal of Comparative Physiology A 192:871-878. doi:10.1007/s00359-006-0126-5.

1759

1760

Lim MLM, Li D (2006b) Extreme ultraviolet sexual dimorphism in jumping spiders (Araneae: Salticidae). Biological journal of the Linneian Society 89:397-406.

1762

1763

Lim MLM, Land MF, Li D (2007). Sex-Specific UV and fluorescence signals in jumping spiders. Science 315(5811):481. doi: 10.1126/science.1134254

1765

1766

Liu MH, Blamires SJ, Liao CP, Tso IM (2014) Evidence of bird dropping masquerading by a spider to avoid predators. Scientific reports, 4:5058. doi: 10.1038/srep05058.

1768

1769

LoPresti EF, Karban R, Robinson M, Grof-Tisza P, Wetzel W (2016) The natural history supplement: furthering natural history amongst ecologists and evolutionary biologists. The Bulletin of the Ecological Society of America 97(3):305-310.

1772

1773

1774

Lubin Y \& Bilde T (2007) The evolution of sociality in spiders. Advances in the Study of Behavior 37:83145. doi:10.1016/S0065-3454(07)37003-4

1776

1777

Machell D (2005) First words. Make Believe Ideas, Hertz, UK

1778

1779

Maher B (2009) Biology's next top model? Nature 458:695-699. doi:10.1038/458695a

1780

1781

Mammola S, Isaia M (2017) Spiders in caves. Proceedings of the Royal Society of London B: Biological 1782 Sciences 284:20170193. doi:10.1098/rspb.2017.0193

1783 
1784 Mammola S, Cavalcante R, Isaia M (2016) Ecological preference of the diving bell spider Argyroneta

1785

1786

1787

1788

1789

1790

1791

1792

1793

1794

1795

1796

1797

1798

1799

1800

1801

1802

1803

1804

1805

1806

1807

1808

1809

1810

1811

1812

1813 1814 aquatica in a resurgence of the Po plain (Northern Italy) (Araneae: Cybaeidae). Fragmenta entomologica 48(1):9-16. doi:10.4081/fe.2016.158

Mammola S, Goodacre SL, Isaia M (2017) Climate change may drive cave spiders to extinction. Ecography 40:1-10. doi:10.1111/ecog.02902

Marc P, Canard A. (1997) Maintaining spider biodiversity in agroecosystems as a tool in pest control. Agriculture, ecosystems \& environment 62(2):229-235.

Marshall SD, Gittleman JL (1994) Clutch size in spiders: is more better? Functional Ecology 118-124. doi: $10.2307 / 2390120$

Marusik YM, Koponen S, Potapova NK (2008) Spiders (Aranei) from Oymyakon, the cold pole of the northern hemisphere (Yakutia, Siberia). Arthropoda Selecta 13(1-2):69-75.

McClain CR, Balk MA, Benfield MC, Branch TA, Chen C, Cosgrove J, Dove ADM, Gaskins LC, Helm RR, Hochberg FG, Lee FB, Marshall A, McMurray SE, Schanche C, Stone SN, Thaler AD. (2015) Sizing ocean giants: patterns of intraspecific size variation in marine megafauna. PeerJ 3:e715. doi:10.7717/peerj.715

McLaughlin J, Metz A (2016) Vision \& Change: Why It Matters. The American Biology Teacher 78(6):456462. doi:10.1525/abt.2016.78.6.456

McQueen DJ, McLay CL (1983) How does the intertidal spider Desis marina (Hector) remain under water for such a long time? New Zealand journal of zoology 10(4):383-391. doi:10.1080/03014223.1983.10423933

Melic A (2002) De madre araña a demonio escorpión: Arácnidos en la mitología. Revista Iberica de Aracnologia 5:112-124. 
1815

1816 Menda G, Shamble PS, Nitzany El, Golden JR, Hoy RR (2014) Visual perception in the brain of a jumping 1817 spider. Current Biology 24(21):2580-2585. doi:10.1016/j.cub.2014.09.029

1818

1819 Menin M, de Jesus Rodrigues D, de Azevedo CS (2005) Predation on amphibians by spiders (Arachnida, Araneae) in the Neotropical region. Phyllomedusa: Journal of Herpetology 4(1):39-47. doi:10.11606/issn.2316-9079.v4i1p39-47

1822

1823 Meehan CJ, Olson EJ, Reudink MW, Kyser TK, Curry RL (2009) Herbivory in a spider through exploitation of an ant-plant mutualism. Current Biology 19(19):892-893.

1825 doi:10.1016/j.cub.2009.08.049

1826

1827

Middendorf G, Pohlad BR (2014) Ecoliteracy for ecology and evolution: eroded underpinnings. Frontiers 1828 in Ecology and the Environment 12:194-195.

1829

1830

Millot J (1949a) Classe de Arachnides (Arachnida). I. - Morphologie generale et anatomie interne. In: Grassé P-P, ed. Traité de Zoologie, 6:263-319.

1832

1833 Millot J (1949b) Ordre de Aranéides. In: Grassé P-P, ed. Traité de Zoologie 6:589-743.

1834

1835

Molur S, Daniel BA, Siliwal M (2008) Poecilotheria metallica. The IUCN Red List of Threatened Species 2008:e.T63563A12681959. doi:10.2305/IUCN.UK.2008.RLTS.T63563A12681959.en.

1837

1838

Moore D, Watts JC, Herrig A, Jones TC (2016) Exceptionally short-period circadian clock in Cyclosa turbinata: regulation of locomotor and web-building behavior in an orb-weaving spider. Journal of Arachnology 44(3):388--396. doi:10.1636/JoA-S-16-014.1

1841

1842 Mulkens SA, de Jong PJ, Merckelbach H (1996) Disgust and spider phobia. Journal of abnormal 1843 psychology 105(3):464-468. doi:10.1037/0021-843X.105.3.464

1844 
1845 Myers N, Mittermeier RA, Mittermeier CG, Da Fonseca GA, Kent J (2000) Biodiversity hotspots for conservation priorities. Nature 403(6772), 853-858. doi:10.1038/35002501

1847

1848

Nelson XJ, Jackson RR (2006). A predator from East Africa that chooses malaria vectors as preferred prey. PLoS ONE 1:e132. doi:10.1371/journal.pone.0000132.

Nelson XJ, Jackson RR (2012) The discerning predator: decision rules underlying prey classification by a mosquito-eating jumping spider. Journal of Experimental Biology 215(13):2255-2261. doi:10.1242/jeb.069609

1854

1855

Nentwig W, Kuhn-Nentwig L (2013a) Main components of spider venoms. In: Nentwig W, ed. Spider ecophysiology. Springer, Berlin, 191-202.

1857

Nentwig W, Kuhn-Nentwig L (2013b) Spider venoms potentially lethal to humans. In: Nentwig W, ed.. Spider ecophysiology. Springer, Berlin, 253-264.

1860

Nyffeler M, Benz G (1987) Spiders in natural pest control: a review. Journal of Applied Entomology

1863

Nyffeler M, Knörnschild M (2013) Bat predation by spiders. PLoS ONE 8(3):e58120. 103(1-5):321-339.

1866

1867

1868

Nyffeler M, Pusey BJ (2014) Fish predation by semi-aquatic spiders: a global pattern. PLoS ONE doi:10.1371/journal.pone.0058120

1869

1870

1871

Nyffeler M, Birkhofer K (2017) An estimated 400-800 million tons of prey are annually killed by the global spider community. The Science of Nature 104(3-4):30. doi:10.1007/s00114-017-1440-1

1872

1873

Nyffeler M, Olson EJ, Symondson WO (2016) Plant-eating by spiders. Journal of Arachnology 44(1):1527. doi:10.1636/P15-45.1

1875

1876

Nyffeler M, Lapinski W, Snyder A, Birkhofer K (2017) Spiders feeding on earthworms revisited: consumption of giant earthworms in the tropics. Journal of Arachnology 45(2):242-247. doi:10.1636/JoA-17-013.1. 
1880 Oliveira U, Brescovit AD, Santos AJ (2017) Sampling effort and species richness assessment: a case study on Brazilian spiders. Biodiversity and Conservation 26:1481. doi:10.1007/s10531-017-1312-1

1882

1883 Paquin P, Vink CJ, Dupérré N (2010) Spiders of New Zealand: Annotated Family Key \& Species. Manaaki Whenua Press.

Peckham GW, Peckham EG (1896) Spiders of the family Attidae from Central America and Mexico. Occasional Papers of the Natural History Society of Wisconsin 3: 1-101.

1888

Pekar S (2014) Comparative analysis of passive defences in spiders (Araneae). Journal of Animal Ecology 83:779-790.

1891

1892

Peñalver E, Grimaldi DA, Delclòs X (2006) Early Cretaceous spider web with its prey. Science

1894

1895

1896

Penney D, Selden PA (2002) The oldest linyphiid spider, in lower Cretaceous Lebanese amber (Araneae,

1897

1898

1899

Pétillon J, Montaigne W, Renault D (2009) Hypoxic coma as a strategy to survive inundation in a saltLinyphiidae, Linyphiinae). Journal of Arachnology 30(3):487-493.

1900

1901

Pickard-Cambridge O (1898) On some Arctic spiders collected during the Jackson-Harmsworth Polar

1902 marsh inhabiting spider. Biology letters 5(4):442-445. doi:10.1098/rsbl.2009.0127

1903 Expedition to the Franz-Josef Archipelago. Journal of the Linnean Society of London, Zoology

1904

1905

Place ES, Evans ND, Stevens MM (2009) Complexity in biomaterials for tissue engineering. Nature

1906 materials 8(6):457-70. doi: 10.1038/nmat2441

1907

1908

Platnick NI (1989) Advances in Spider Taxonomy 1981-1987: a supplement to Brignoli's A Catalogue of 1909 the Araneae described between 1940 and 1981. Manchester University Press.

1910 
1911 Platnick NI (1993) Advances in spider taxonomy 1988-1991, with synonymies and transfers 1940-1980.

1912 The New York Entomological Society, New York.

1913

1914 Platnick NI (1998) Advances in spider taxonomy 1992-1995 with redescriptions 1940-1980. New York $1915 \quad$ Entomological Society, New York.

1916

1917 Platnick NI (2000-2014) Archive of the World Spider Catalog by Norman I. Platnick. American Museum of Natural History. Online at: http://www.wsc.nmbe.ch/archive/. Accessed: 09 Jan 2017.

1919

1920

1921

Platnick NI, Baehr B (2006) A revision of the Australasian ground spiders of the family Prodidomidae 1922

1923

Poinar G, Buckley R (2012) Predatory behaviour of the social orb-weaver spider, Geratonephila burmanica n. gen., n. sp. (Araneae: Nephilidae) with its wasp prey, Cascoscelio incassus n. gen.,

1925

1926 n. sp.(Hymenoptera: Platygastridae) in Early Cretaceous Burmese amber. Historical Biology

1927

1928

Priddy R, (2004) My Little Word Book. St Martin's press, New York.

1929

Prokop P, Maxwell MR (2012) Gift carrying in the spider Pisaura mirabilis: nuptial gift contents in nature 24(5):519-525. doi:10.1080/08912963.2011.640399

1932 and effects on male running speed and fighting success. Animal Behavior 83(6):1395-1399.

1933 doi:10.1016/j.anbehav.2012.03.007

1935

Prum RO, Berv JS, Dornburg A, Field DJ, Townsend JP, Lemmon EM, Lemmon AR (2015) A comprehensive phylogeny of birds (Aves) using targeted next-generation DNA sequencing. Nature

Pugh PAJ (2004) Biogeography of spiders (Araneae: Arachnida) on the islands of the Southern Ocean. Journal of Natural History 38(12):1461-1487

1940

1941

Quesada R, Triana E, Vargas G, Douglass JK, Seid MA, Niven JE, Eberhard WG, Wcislo, WT (2011) The allometry of CNS size and consequences of miniaturization in orb-weaving and cleptoparasitic spiders. Arthropod Structure \& Development 40(6):521-529. doi10.1016/j.asd.2011.07.002

1944 
1945 Ray N (2002) Lonely Planet Cambodia. Lonely Planet Publications.

1946

1947

Řezáč M, Pekar, S. (2007) Evidence for woodlice-specialization in Dysdera spiders: behavioral versus developmental approaches. Physiological Entomology 32(4):367-371. doi:10.1111/j.13653032.2007.00588

1950

Rinck M, Becker ES (2007) Approach and avoidance in fear of spiders. Journal of behavior therapy and experimental psychiatry 38(2):105-120. doi:10.1007/s10826-010-9402-7

Rix MG, Harvey MS (2011) Australian Assassins, Part I: a review of the assassin spiders (Araneae, Archaeidae) of mid-eastern Australia. ZooKeys 123:1-100. doi:10.3897/zookeys.123.1448

Rix MG, Huey JA, Main BY, Waldock JM, Harrison SE, Comer S, Austin AD, Harvey MS (2016) Where have all the spiders gone? The decline of a poorly known invertebrate fauna in the agricultural and arid zones of southern Australia. Austral Entomology 56:14-22. doi:10.1111/aen.12258

Robinson MH, Robinson B (1971) The predatory behavior of the ogre-faced spider Dinopis longipes F. Cambridge (Araneae: Dinopidae).

American

Midland

Naturalist $\quad 85: 85-96$ doi:10.2307/2423914

Robinson MH, Robinson B (1976) The ecology and behavior of Nephila maculata: a supplement.

Roewer CF (1942) Katalog der Araneae von 1758 bis 1940. Bremen 1:1-1040.

Roewer CF (1955) Katalog der Araneae von 1758 bis 1940, bzw. 1954. Bruxelles 2:1-1751.

Rovner JS (1986) Nests of terrestrial spiders maintain a physical gill: flooding and the evolution of silk constructions. Journal of Arachnology 14:327-337.

Saez NJ, Senff S, Jensen JE, Er SY, Herzig V, Rash LD, King GF (2010) Spider-venom peptides as therapeutics. Toxins 2(12):2851-2871. doi:10.3390/toxins2122851 
1978 Sand-Jensen K (2007) How to write consistently boring scientific literature. Oikos 116(5):723-727. doi:

1980

Sanggaard KW, Bechsgaard JS, Fang X, Duan J, Dyrlund TF, Gupta V, Jiang X, Cheng L, Fan D, Feng Y, Han L, Huang Z, Wu Z, Liao L, Settepani V, Thøgersen IB, Vanthournout B, Wang T, Zhu Y, Funch P, Enghild JJ, Schauser L, Andersen SU, Villesen P, Schierup MH, Bilde T, Wang J (2014) Spider genomes provide insight into composition and evolution of venom and silk. Nature

Sarkar P, Phaneendra S, Chakrabarti A (2008) Developing engineering products using inspiration from nature. Journal of Computing and Information Science in Engineering 8(3):031001. doi:10.1115/1.2956995

1990

1991

Schaefer L, Plotnikoff RC, Majumdar SR, Mollard R, Woo M, Sadman R, Rinaldi RL, Boulé N, Torrance B, Ball GD, Veugelers P, Wozny P, McCargar L, Downs S, Lewanczuk R, Gleddie D, McGavock J (2014) Outdoor time is associated with physical activity, sedentary time, and cardiorespiratory

Schiödte JC (1847) Forelöbig Beretning om Untersögelser om den underjordiske Fauna i Hulerme i Krain og Istrien. Oversigt over det Kongelige Danske Videnskabernes Selskabs Forhandlinger 1847:7581.

1999

2000

2001

Schmitt WJ, Müri RM (2009) Neurobiologie der Spinnenphobie. Schweizer Archiv für Neurologie

2002

2003

Schneider JM (1996) Differential mortality and relative maternal investment in different life stages in Stegodyphus lineatus (Araneae, Eresidae). Journal of Arachnology 24(2):148-154

2005

2006

Schultz SA, Schultz, MJ (1998) The Tarantula Keeper's Guide. Barron's Educational Series, ISBN 2007 0764100769.

2008 
2009

2010

2011

2012

2013

2014

2015

2016

2017

2018

2019

2020

2021

2022

2023

2024

2025

2026

2027

2028

2029

2030

2031

2032

2033

2034

2035

2036

2037

2038

2039

2040

2041
Schütz D, Taborsky M (2003) Adaptations to an aquatic life may be responsible for the reversed sexual size dimorphism in the water spider, Argyroneta aquatica. Evolutionary Ecology Research 5:105117.

Schütz D, Taborsky M (2005) Mate choice and sexual conflict in the size dimorphic water spider Argyroneta aquatica (Araneae, Argyronetidae). Journal of Arachnology 33: 767-775. doi:10.1636/S03-56.1

Schwager EE, Sharma PP, Clarke T, Leite DJ, Wierschin T, Pechmann M, Akiyama-Oda Y, Esposito L, Bechsgaard J, Bilde T, Buffry AD, Chao H, Dinh H, Doddapaneni HV, Dugan S, Eibner C, Extavour CG, Funch P, Garb K, Gonzalez LB, Gonzalez VL, Griffiths-Jones S, Han Y, Hayashi C, Hilbrant M, Hughes DST, Janssen R, Lee SL, Maeso I, Murali SC, Muzny DM, Nunes da Fonseca R, Paese CLB, Qu JX, Ronshaugen M, Schomburg C, Schönauer A, Stollewerk A, Torres-Oliva M, Turetzek N, Vanthournout B, Werren JH, Wolff C, Worley KC, Bucher G, Gibbs RA, Coddington J, Oda H, Stanke M, Ayoub NA, Prpic NM, Flot JF, Posnien N, Richards S, McGregor AP (2017) The house spider genome reveals an ancient whole-genome duplication during arachnid evolution. BMC Biology 15:62. doi:10.1186/s12915-017-0399-x

Schwartz SK, Wagner WE, Hebets EA (2013) Spontaneous male death and monogyny in the dark fishing spider. Biology letters 9(4):20130113. doi:10.1098/rsbl.2013.0113

Schwartz SK, Wagner WE, Hebets EA (2016) Males can benefit from sexual cannibalism facilitated by self-sacrifice. Current Biology 26(20):2794-2799. doi:10.1016/j.cub.2016.08.010

Schwenk K, Padilla DK, Bakken GS, Full RJ (2009) Grand challenges in organismal biology. Integrative and Comparative Biology 49(1):7-14. doi:10.1093/icb/icp034

Selden PA (1996) First fossil mesothele spider, from the Carboniferous of France. Revue Suisse de Zoologie 2:585-596.

Selden PA, Penney D (2010) Fossil spiders. Biological Reviews 85(1):171-206. doi:10.1111/j.1469185X.2009.00099 
2042 Selden PA, Shih C, Ren D (2011) A golden orb-weaver spider (Araneae: Nephilidae: Nephila) from the $2043 \quad$ Middle Jurassic of China. Biology letters 7(5):775-778. doi:10.1098/rsbl.2011.0228

2044

2045

Selden PA, Shih C, Ren D (2013) A giant spider from the Jurassic of China reveals greater diversity of the 2046 orbicularian stem group. Naturwissenschaften 100(12):1171-1181. doi:10.1007/s00114-013-1121-7

2047

2048

Sendra A, Reboleira ASPS (2012) The world deepest subterranean community - Krubera-Voronja Cave (Western Caucasus). International Journal of Speleology 41(2):221-230. doi:10.10070.5038/1827806X.41.2.9

2051

2052

Seymour RS, Hetz SK (2011) The diving bell and the spider: the physical gill of Argyroneta aquatica. Journal of Experimental Biology 214: 2175-2181. doi:10.1242/jeb.056093

2054

2055

Shamble PS, Menda G, Golden JR, Nitzany El, Walden K, Beatus T, Elias DO, Cohen I, Miles RN, Hoy 2056

2057 RR (2016) Airborne acoustic perception by a jumping spider.Current Biology 26(21):2913-2920.

2058

2059

Smith DR (1986) Population genetics of Anelosimus eximius (Araneae, Theridiidae). Journal of

2060

Arachnology 14:201-217.

2061

2062

Smithers P, Whitehouse A (2016) Nothophantes horridus, Possibly the Rarest Spider in the World; a brief 2063 history. Newsletter of the Brititsh Arachnological Society 135:4-5.

2064

2065

Smith-Janik S, Teachman BA (2008) Impact of priming on explicit memory in spider fear. Cognitive 2066 Therapy and Research 32:291-302.

2067

2068

Sobral M, Stehmann JR (2009) An analysis of new angiosperm species discoveries in Brazil (19902069 2006). Taxon 58:227-232. doi:10.1590/2175-7860201566411

2070

2071 Stafstrom JA, Hebets EA (2016) Nocturnal foraging enhanced by enlarged secondary eyes in a net2072 casting spider. Biology letters 12(5):20160152. doi:10.1098/rsbl.2016.0152 
2073

2074 Suter RB (1999) Cheap transport for fishing spiders (Araneae, Pisauridae): the physics of sailing on the

2075 water surface. Journal of Arachnology 27:489-96.

2076

2077

Suter RB (2013) Spider locomotion on the water surface: biomechanics and diversity. Journal of 2078 Arachnology 41(2):93-101: doi:10.1636/M13-14

2079

2080

Suter RB, Stratton GE (2009) Spitting performance parameters and their biomechanical implications in

2081

2082 the spitting spider, Scytodes thoracica. Journal of Insect Science 9(1):62. doi:10.1673/031.009.6201

2083

2084

Tewksbury JJ, Anderson JG, Bakker, JD, Billo TJ, Dunwiddie PW, Groom MJ, Hampton SE, Herman SG,

2085 Levey DJ, Machnicki NJ, del Rio CM, Power ME, Rowell K, Salomon AK, Stacey L, Trombulak

2086

2087 SC, Wheeler TA (2014) Natural history's place in science and society. BioScience 64(4):300-310.

2088

2089

Tremblay MS, Gray CE, Akinroye K, Harrington DM, Katzmarzyk PT, Lambert EV, Liukkonen J, Maddison

2090 R, Ocansey RT, Onywera VO, Prista A, Reilly JJ, Rodríguez Martínez MP, Sarmiento Duenas OL,

2091

2092 Standage M, Tomkinson G (2014) Physical activity of children: a global matrix of grades comparing

2093

2094

Tseng L, Tso IM (2009) A risky defence by a spider using conspicuous decoys resembling itself in

2095 appearance. Animal Behavior 78(2):425-431. doi:10.1016/j.anbehav.2009.05.017

2096

2097

2098

Turnbull AL (1973) Ecology of the true spiders (Araneomorphae). Annual Review of Entomology 18: 305-

2099 348. doi:10.1146/annurev.en.18.010173.001513

2100

2101

Uetz GW, Stratton GE (1982) Acoustic communication and reproductive isolation in spiders. In: Witt PN,

2102

2103 Rovner JS, ed. Spider communication: mechanisms and ecological significance. Princeton, 123159.

2104

2105

Van Hasselt AWM (1884) Waarnemingen omtrent anomaliën van de geslachtsdrift bij spinnen-mares.

2106 Tijdschrift voor Entomologie 27:197-206.

2107 
2108 Vetter RS, Isbister GK (2008) Medical aspects of spider bites. Annual Review of Entomology 53, 409-429. doi:10.1146/annurev.ento.53.103106.093503

2110

2111 Vink CJ (2015) A Photographic Guide to Spiders of New Zealand (Photographs by Bryce McQuillan). 2112 Auckland: New Holland.

2113

2114 Vollrath F (1987) Kleptobiosis in spiders. In: Nentwig W, ed. Ecophysiology of Spiders Nentwig Springer2115 Verlag, Berlin, 274-286.

2116

Wanless FR (1975) Spiders of the family Salticidae from the upper slopes of Everest and Makalu. Bulletin of the British Arachnological Society 3:132-136.

2119

2120

2121

Watson W, Walker HJ (2004) The world's smallest vertebrate, Schindleria brevipinguis, a new paedomorphic species in the family Schindleriidae (Perciformes: Gobioidei). Records of the

2123

2124

Weng JL, Barrantes G, Eberhard WG (2006) Feeding by Philoponella vicina (Araneae, Uloboridae) and

2125 how uloborid spiders lost their venom glands. Canadian Journal of Zoology 84:1752-1762. doi:10.1007:10.1139/Z06-149

2127

2128

2129 Australian Museum 56(2):139-142. doi: 10.3853/j.0067-1975.56.2004.1429

2130

2131

2132

2133

2134

Wesolowska W, Jackson RR (2003) Evarcha culicivora sp. nov., a mosquito-eating jumping spider from East Africa (Araneae: Salticidae). Annales Zoologici, Warszawa 53:335-338.

Wheeler WH, Coddington JA, Crowley LM, Dimitrov D, Goloboff PA, Griswold CE, Hormiga G, Prendini L, Ramírez MJ, Sierwald P, Almeida-Silva LM, Álvarez-Padilla F, Arnedo MA, Benavides Silva LR, Benjamin SP, Bond JE, Grismado CJ, Hasan E, Hedin M, Izquierdo MA, Labarque FM, Ledford J, Lopardo L, Maddison WP, Miller JA, Piacentini LN, Platnick NI, Polotow D, Silva-Dávila D, Scharff N, Szüts T, Ubick D, Vink CJ, Wood HM, Zhang JX (2017) The spider tree of life: phylogeny of 22(1):65-68. doi:10.1097/00007691-200002000-00014 
2142 Whitehouse MEA \& Lubin Y (2005) The functions of societies and the evolution of group living: Spider 2143 societies as a test case. Biological Reviews 80:1-15. doi:10.1017/S1464793104006694

2144

2145 Wilson JB, Peet RK, Dengler J, Pärtel M (2012) Plant species richness: the world records. Journal of vegetation Science 23(4):796-802. doi:10.1111/j.1654-1103.2012.01400

Witt PN, Scarboro MB, Daniels R, Peakall DB, Gause RL (1976) Spider web-building in outer space: evaluation of records from the Skylab spider experiment. Journal of Arachnology 4:115-124.

2150

2151

Wood HM, Griswold CE, Gillespie RG (2012) Phylogenetic placement of pelican spiders (Archaeidae, Araneae), with insight into evolution of the "neck" and predatory behaviors of the superfamily Palpimanoidea Cladistics 28(6):598-626..doi:10.1111/j.1096-0031.2012.00411

2154

2155

Wood HM, Parkinson DY, Griswold CE, Gillespie RG, Elias DO (2016) Repeated evolution of poweramplified predatory strikes in trap-jaw spiders. Current Biology 26(8):1057-1061. doi:10.1016/j.cub.2016.02.029

2158

2159

Woody SR, McLean C, Klassen T (2005) Disgust as a motivator of avoidance of spiders. Journal of anxiety disorders 19(4):461-475. doi:10.1016/j.janxdis.2004.04.002

2161

2162

World Spider Catalog-WSC (2017) World Spider Catalog (Version 18.5). Natural History Museum Bern. Online at: http://wsc.nmbe.ch. Accessed: 03 Oct 2017

2164

2165

World spider Catalog Archive (2014-2017) Archive of the World Spider Catalog. Museum of Natural History Bern. Online at http://wsc.nmbe.ch/archive. Accessed: 09 Jan 2017

2167

2168 Yeargan KV (1994) Biology of Bolas Spiders. Annual Review of Entomology 39:81-99. 2169 doi:10.1146/annurev.en.39.010194.000501 
2171 Zobel-Thropp PA, Correa SM, Garb JE, Binford GJ (2013) Spit and venom from scytodes spiders: a 2172 diverse and distinct cocktail. Journal of proteome research 13(2):817-835. doi:10.1021/pr400875s

2173

2174 Zonstein S, Marusik YM (2013) Checklist of the spiders (Araneae) of Israel. Zootaxa 3671(1):1-127. 2175 doi:10.11646/zootaxa.3671.1.1

2176

2177 Zurek DB, Nelson XJ (2012) Hyperacute motion detection by the lateral eyes of jumping spiders. Vision 2178 research 66:26-30. doi:10.1016/j.visres.2012.06.011

2179

2180 Zurek DB, Taylor A, Evans CS, Nelson XJ (2010) The role of the anterior lateral eyes in the vision-based 2181 behaviour of jumping spiders. Journal of Experimental Biology 213(14): 2372-2378.

2182 doi:10.1242/jeb.042382

2183

2184

2185 


\section{Figure 1 (on next page)}

General anatomy of a spider and variation in body forms.

Dorsal view of a spider showing its general organization and variation in its appearance exemplified by few representative of the 113 known spider families. 


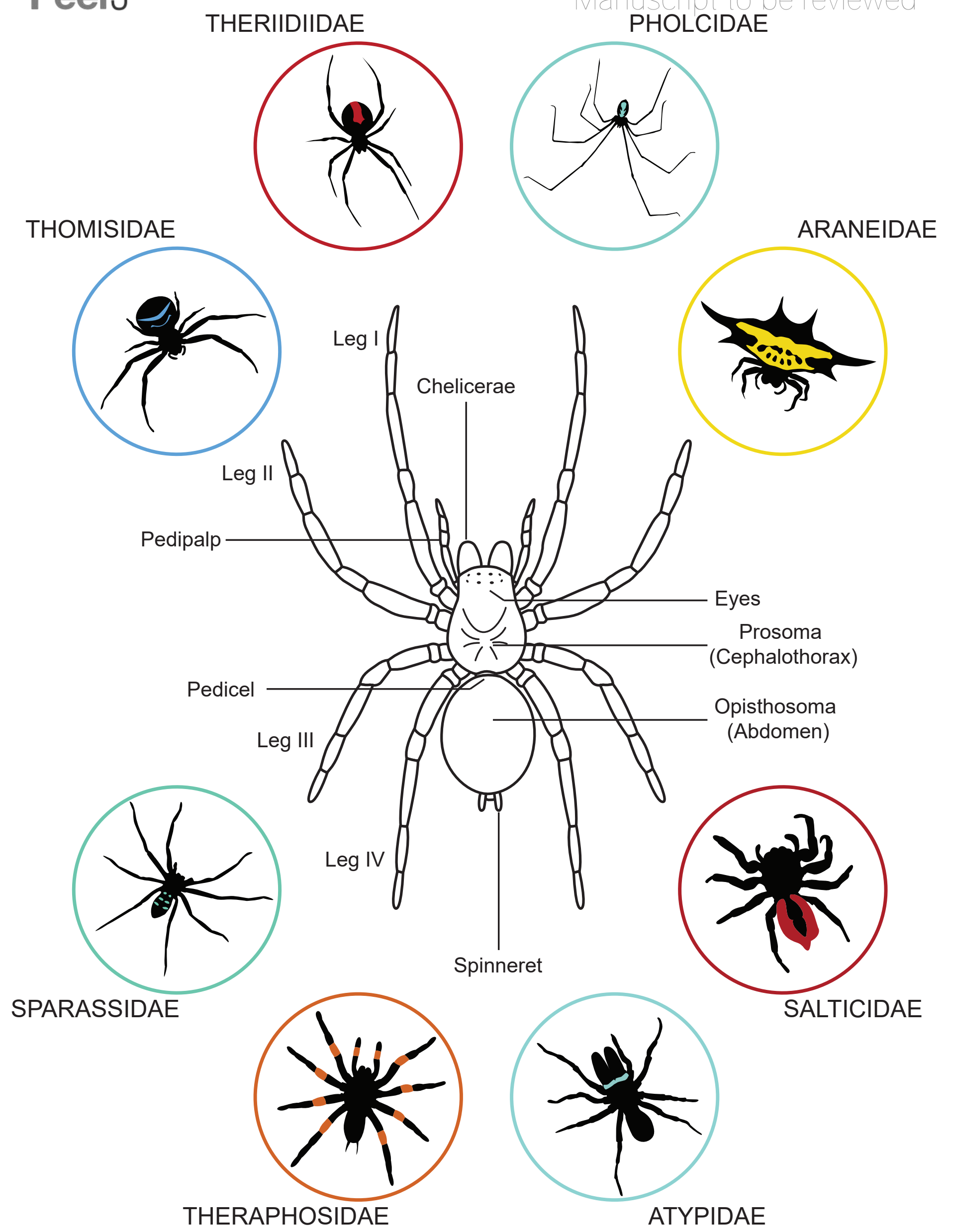




\section{Figure 2 (on next page)}

Taxonomy, arachnology and arachnologists.

a) Original illustrations of some of the first spiders described in binomial nomenclature (Modified from Clerck, 1757); b) Eugène Louis Simon (1848-1924), the most prolific arachnologist in history (Photo credit: en.wikipedia.org); c) The first Congress of Arachnology in history at the University of Bonn (Germany) in 1960 (Kraus, 1999); d) The largest congress of Arachnology (2-9 July 2016, Golden, Colorado, USA) (Photo credit: Paula Cushing Congress Organizing committee). 


\section{Figure 3 (on next page)}

Morphology and physiology.

a) The Goliath bird-eater, Theraphosa blondi (Latreille) (Theraphosidae), the largest known spider by mass (Photo credit: Steve Le Roux); b) Heteropoda maxima Jäger (Sparassidae), the largest known spider by leg span, in its typical ambushing position (Photo credit: Peter Jäger); c) The enlarged posterior median eyes of a net-casting spider (Deinopis sp., Deinopidae) (Photo credit: Michael Doe) d) Stalita taenaria Schiödte (Dysderidae), the first eyeless spider ever described (Photo credit: Fulvio Gasparo); e ) The Darwin's bark spider, Caerostris darwin i Kuntner \& Agnarsson ( Araneidae), produces the toughest known spider silk (Photo credit: Matjaž Kuntner); f ) The web of the Darwin's bark spider can reach an area of $2.8 \mathrm{~m}^{2}$, being therefore the largest orb web ever measured (Photo credit: Matjaž Kuntner); $\mathbf{g}$ ) Golden orb weaving spiders (Nephilidae) exemplify the most extreme malebiased sexual size dimorphism in spiders. The white arrow points at the male (Photo credit: Matjaž Kuntner). 


\section{Figure 4 (on next page)}

Ecology and behavior.

a) A ballooning spider - numerous spiders can disperse through the air by releasing one silk threads to catch the wind (Photo credit: Lacey Szymanski - Pieceoflace photography); b) A fishing spider, Dolomedes spp. (Pisauridae), capable of effective locomotion on the surface of water (Photo credit: Olaf Craasmann); c) A male and female of the one-palped spider Tidarren argo Knoflach \& van Harten (Theridiidae) during the copula: in this species, the male dies almost immediately after the insertion of his copulatory organ and is usually cannibalized by the female afterwards (Photo credit: Barbara Knoflach-Thaler); d) A cavedwelling spider of the genus Troglohyphantes. In some species, a protracted mating lasting >18 hours was observed (Photo credit: Francesco Tommasinelli); e) A male of Maratus elephans Otto \& Hill (Salticidae) performing its courtship display (Photo credit: Adam Fletcher); f) The water spider, Argyroneta aquatica (Clerck) (Cybaeidae), the only known spiders living a wholly aquatic life (Photo credit: Riccardo Cavalcante); g) Bagheera kiplingi Peckham \& Peckham (Salticidae), the only known spider with a mostly herbivorous diet-it predominantly consumes specialized leaf tips of Acacia (Photo credit: Maximilian Paradiz via Wikipedia); h) A kleptoparasitic spider (Theridiidae: Argyrodes sp.) dwelling in the web of a Tropical Tent-Web Spider, Cyrtophora citricola (Araneidae) (Photo credit: Emanuele Biggi). 

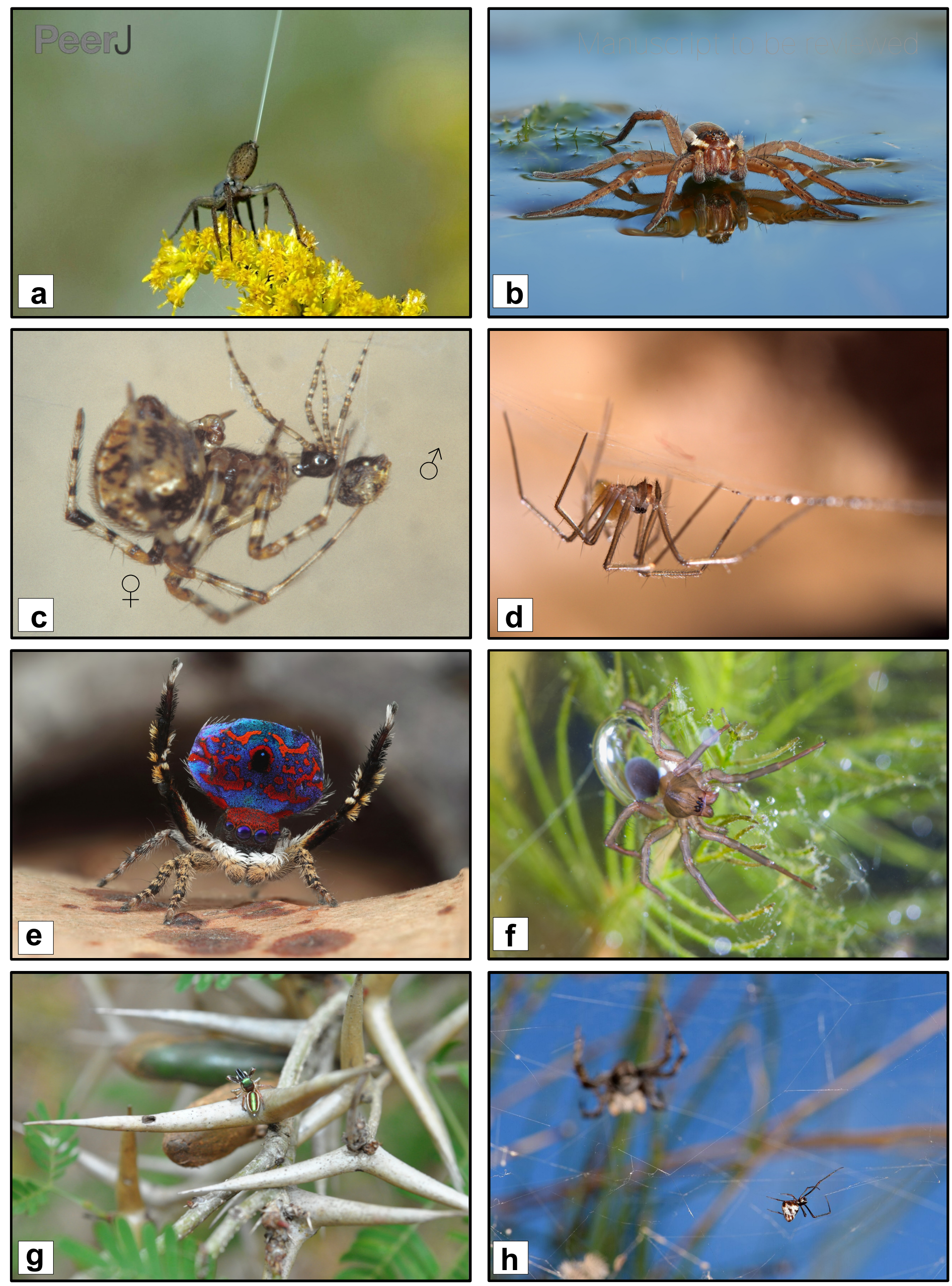
Table $\mathbf{1}$ (on next page)

General organization of the Spider world record. 


\begin{tabular}{|c|c|c|}
\hline \multicolumn{2}{|c|}{$\begin{array}{l}\text { I. Arachnology and } \\
\text { Arachnologists }\end{array}$} & $\begin{array}{l}\text { a. First arachnologist in history } \\
\text { b. } \\
\text { c. }\end{array}$ \\
\hline \multicolumn{2}{|c|}{ II. Paleontology } & 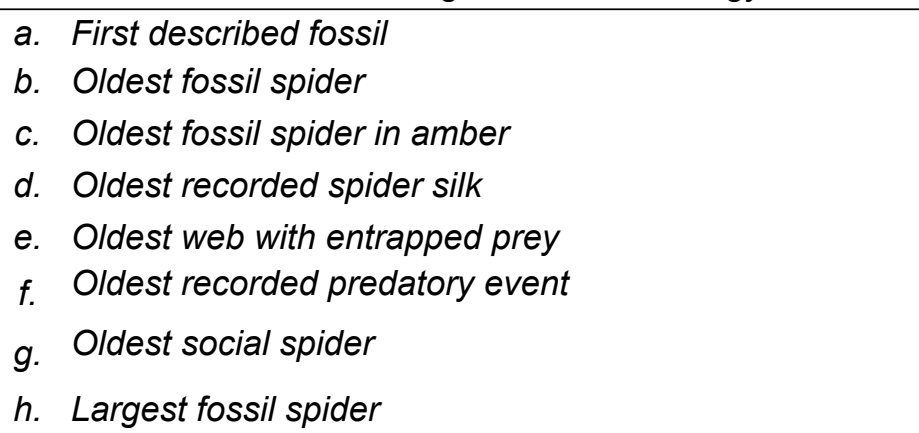 \\
\hline \multicolumn{2}{|c|}{ III. Taxonomy and Systematics } & $\begin{array}{ll}\text { a. } & \text { First spider(s) ever described in binomial nomenclature } \\
\text { b. } & \text { First listed spider alphabetically } \\
\text { c. } & \text { Last listed spider alphabetically } \\
\text { d. } & \text { Longest scientific name } \\
\text { e. } & \text { Shortest scientific name } \\
\text { f. } & \text { Largest spider family } \\
\text { g. } & \text { Smallest spider family } \\
\text { h. } & \text { First entire genome sequenced } \\
\text { i. } & \text { Most species named after celebrities within one genus }\end{array}$ \\
\hline \multirow{3}{*}{ IV. Anatomy } & 1. Size & $\begin{array}{l}\text { a. Largest living spiders } \\
\text { b. Smallest adult female spider } \\
\text { c. Smallest adult male spider } \\
\text { d. Most extreme sexual size dimorphism } \\
\text { e. }\end{array}$ \\
\hline & 2. Body parts & $\begin{array}{l}\text { a. } \text { Highest number of eyes } \\
\text { b. Least number of eyes } \\
\text { c. Largest eyes } \\
\text { d. Longest relative chelicerae } \\
\text { e. Largest relative fangs } \\
\text { f. Longest relative walking legs } \\
\text { g. } \text { Most legs } \\
\text { h. } \\
\text { i. } \text { Lost spinnerets } \\
\text { Longest relative spinnerets }\end{array}$ \\
\hline & $\begin{array}{l}\text { 3. Internal } \\
\text { organs }\end{array}$ & $\begin{array}{l}\text { a. Largest central nervous system } \\
\text { b. Largest relative venom glands } \\
\text { c. Smallest relative venom glands }\end{array}$ \\
\hline V. Physiology & 1. Silk and webs & $\begin{array}{l}\text { a. Largest web (area) } \\
\text { b. Largest web (length) } \\
\text { c. Smallest web }\end{array}$ \\
\hline
\end{tabular}




\begin{tabular}{|c|c|c|}
\hline & & $\begin{array}{ll}\text { d. } & \text { Strongest silk } \\
\text { e. } & \text { Strongest cocoon silk }\end{array}$ \\
\hline & 2. Venom & $\begin{array}{l}\text { a. Most venomous to humans } \\
\text { b. Least venomous } \\
\text { c. Most unusual venom }\end{array}$ \\
\hline & $\begin{array}{l}\text { 3. Sensory } \\
\text { organs }\end{array}$ & $\begin{array}{l}\text { a. Best diurnal eyesight } \\
\text { b. Best nocturnal eyesight } \\
\text { c. Best hearing } \\
\text { d. } \text { Most bioluminescent }\end{array}$ \\
\hline & $\begin{array}{l}\text { 4. Biological } \\
\text { cycle }\end{array}$ & $\begin{array}{l}\text { a. Longest life span } \\
\text { b. Shortest circadian rhythm }\end{array}$ \\
\hline & $\begin{array}{l}\text { 5. Eggs and } \\
\text { sperms }\end{array}$ & $\begin{array}{l}\text { a. Longest sperm } \\
\text { b. Highest number of eggs } \\
\text { c. Least number of eggs }\end{array}$ \\
\hline & 1. Locomotion & $\begin{array}{l}\text { a. Best ballooners } \\
\text { b. Best sailors } \\
\text { c. Fastest spider } \\
\text { d. Fastest rotational movement }\end{array}$ \\
\hline & 2. Foraging & $\begin{array}{l}\text { a. Most creative hunting strategies } \\
\text { b. Fastest predatory strike } \\
\text { c. Largest invertebrate prey } \\
\text { d. Largest vertebrate prey } \\
\text { e. Strangest diet } \\
\text { f. Fussiest spider }\end{array}$ \\
\hline VI. Behavior & 3. Reproduction & $\begin{array}{ll}\text { a. } & \text { Shortest Mating } \\
\text { b. } & \text { Longest mating } \\
\text { c. } & \text { Best date } \\
\text { d. } & \text { Most elaborate courtship } \\
\text { e. } & \text { Most complex song } \\
\text { f. Loudest spider } \\
\text { g. } \text { Best mother } \\
\text { h. } \text { Best father }\end{array}$ \\
\hline & 4. Lifestyle & $\begin{array}{l}\text { a. Most peaceful } \\
\text { b. Largest colony } \\
\text { c. Best thieves } \\
\text { d. Best camouflage } \\
\text { e. Longest time under water } \\
\text { f. Longest time under water in a nest }\end{array}$ \\
\hline VII. Ecology & 1. Habitat & $\begin{array}{l}\text { a. Highest altitude } \\
\text { b. Lowest altitude } \\
\text { c. Coldest place inhabited by spiders } \\
\text { d. Hottest place inhabited by spiders } \\
\text { e. Northernmost species } \\
\text { f. Southernmost species }\end{array}$ \\
\hline
\end{tabular}




\begin{tabular}{|c|c|c|}
\hline & & $\begin{array}{cl}\text { g. } & \text { Most diverse habitat } \\
\text { h. } & \text { Least suitable habitat } \\
i . & \text { Strangest habitat }\end{array}$ \\
\hline & 2. Conservation & $\begin{array}{ll}\text { a. } & \text { Rarest } \\
\text { b. } & \text { Most endangered } \\
\text { c. } & \text { Most wanted as pet }\end{array}$ \\
\hline \multicolumn{2}{|l|}{ VIII. Curiosities } & $\begin{array}{l}\text { a. The longest journey } \\
\text { b. Most delicious } \\
\text { c. Most eaten by humans } \\
\text { d. Most feared } \\
\text { f. Largest item of clothing woven from spider silk } \\
\text { g. Most iconic spider }\end{array}$ \\
\hline
\end{tabular}

1 